\title{
What Drives Entrepreneurial Orientation in the Public Sector? Evidence from Germany's Federal Labor Agency
}

\author{
Timo Meynhardt, * Fabian E. Diefenbach ${ }^{\dagger}$ \\ *University of St Gallen; ${ }^{\dagger}$ Bain \& Company Germany
}

\begin{abstract}
Along with the introduction of private sector management tools, public servants are expected to act more entrepreneurially-as public managers. However, research lacks quantitative evidence on what drives entrepreneurial orientation (EO) in this context. Our article examines the antecedents of department-level EO in public sector organizations. By integrating different research streams into one study, we combine partly opposing discourses. This deductive study develops and empirically tests hypotheses on antecedents identified from private sector corporate entrepreneurship literature and from the current debate on new public management and public value management. It uses data from 250 middle managers of Germany's Federal Labor Agency to do so. Contrary to expectations, the influence of management support, work discretion, and resources is only limited. Furthermore, a focus on key performance indicators and goal ambiguity does not seem to impede EO. Instead, a multitude of expectations, middle managers' localism, and position tenure have the greatest impact on department-level EO. As a result, this study provides insights into the strong role of antecedents outside of administration. The article concludes with a discussion of implications for both theory and practice.
\end{abstract}

\section{INTRODUCTION}

The notion of entrepreneurship poses specific challenges for public administration. In areas of discretion and leeway, any organizational context clearly requires nonroutine or creative behavior. However, as with public organizations, we know little about the actual antecedents of entrepreneurship, that is, what makes public administration innovative, proactive, and sometimes even risk taking (Currie et al. 2008; Morris and Jones 1999). Despite the basic idea's prominence, empirical evidence has been lacking.

Entrepreneurship within existing organizations, often referred to as corporate entrepreneurship, has been studied extensively within the private sector (Covin and Slevin 1991; Guth and Ginsberg 1990; Miller 1983). Consensus on both the antecedents and outcomes of corporate entrepreneurship has emerged (Zahra, Jennings, and Kuratko 1999; Rauch et al.

\footnotetext{
We would like to thank Steffen Bartholomes, Torsten Schmid, Thomas Zellweger, and three anonymous reviewers for their helpful comments on earlier versions of this article. Address correspondence to the author at timo.meynhardt@unisg.ch.
}

doi:10.1093/jopart/mus013

(c) The Author 2012. Published by Oxford University Press on behalf of the Journal of Public Administration Research and Theory, Inc. All rights reserved. For permissions, please e-mail: journals.permissions@oup.com 
2009). Despite the idea that organizational determinants may not outweigh general human tendencies with regard to risk taking and innovation, the blind transfer of concepts between the private and public sectors appears inappropriate given the substantial differences in their purpose and mission (Pettigrew, Ferlie, and McKee 1992, 13; Rainey 2009, 60-4).

In the public sector, where private sector management principles have been introduced over the past decades under the doctrine of new public management (NPM) (for an overview, see Pollitt and Bouckaert 2004; Hood 1991), entrepreneurship is called for as a means to improve performance (e.g., Osborne and Gaebler 1992; Bellone and Goerl 1992). Because NPM primarily focuses on service delivery, it restricts the notion of entrepreneurship to the managerial part of implementing any given policy (O'Flynn 2007; Stoker 2006). In fact, NPM comes close to what is called "managerialism" (see Terry 1998). Critics of entrepreneurship in the public sector even point to potential threats to democratic governance and note the detrimental effects of rule breaking, competition, and self-interested managers (deLeon and Denhardt 2000; Du Gay 2000; Rhodes and Wanna 2007; Terry 1998).

The creation of the public value (PV) concept, as proposed by Moore (1995), has been a prominent attempt to reconcile the entrepreneurial impetus of NPM with an appreciation of a public organization's broader normative functions in society. Moore "equates managerial success in the public sector with initiating and reshaping public sector enterprises in ways that increase their value to the public in both the short and the long run" $(1995,10)$. The notion of value creation for the public provides a much broader perspective than the NPM perspective as it includes managerial efficiency concerns and explicitly considers the multitude of values affected, created, or destroyed by an administration. Value creation frames public entrepreneurship as a means of increasing its value to the public (Meynhardt 2009). Such PV creation - in the tradition of Waldo's notion of a value-laden administration (1948/2007) — not only includes a spectrum of instrumental-utilitarian aspects, such as spending tax money efficiently and solving social problems, but also normative aspects of moral and political values beyond financial or economic value (Meynhardt and Bartholomes 2011).

A PV creation perspective explicitly relates entrepreneurship to the complexity of societal challenges and the fuzzy boundaries between politics and administration. Typically, the legal mandate determines the PV to be created. However, it requires not only efficient management of the immediate tasks at hand but a proactive approach to note the broader consequences of social problems and to act according to set rules. Public value management (PVM) involves entrepreneurial behaviors to spot new opportunities, facilitate co-production with citizens and other institutions, and implement ideas to better fulfill the legal mandate.

It is this highly political setting of balancing policy making and execution in a given state environment - along with greater goal ambiguity, less decision-making autonomy for managers, and risk/reward trade-offs - that draws the distinction between public sector and private sector entrepreneurship (Bernier and Hafsi 2007, 490; Currie et al. 2008, 990; Morris and Jones 1999, 77-8). Entrepreneurship always involves risk and uncertainty, although a public organization has inherent specifics as it is subject to public law and requires legitimacy, which is created through a political process.

In the private sector context, a set of organizational antecedents of corporate entrepreneurship has been established for middle managers (Hornsby, Kuratko, and Zahra 2002; 
Kuratko et al. 2005). The perception of these antecedents (Marginson 2002) influences the extent to which middle managers behave entrepreneurially (Hornsby et al. 2009). In the public sector, middle managers are identified as the most entrepreneurial people (Morris and Jones 1999, 83), the largest group of initiators (Borins 2000, 500), and the main source of creativity in entrepreneurship (Bernier and Hafsi 2007, 494). Such a positive view of middle managers' contributions cannot, however, be taken for granted. Researchers have argued that this management level could also be seen as a major barrier to change and strategic renewal (Balogun 2003; Guth and MacMillan 1986). Obviously, at times, the zeitgeist in management doctrines fosters a rather positive image and at other times a rather negative image of this management layer (Currie and Procter 2005; Wooldridge, Schmid, and Floyd 2008). Either way, middle managers may be regarded as the eye of the needle through which ideas need to pass if they are to be realized.

Despite the increased importance of entrepreneurship in the public sector, there is little empirical research on the topic. Even fewer studies have examined antecedents (e.g., Kearney, Hisrich, and Roche 2008; Teske and Schneider 1994), and middle managers have only recently become the focus of some (qualitative) research (Currie and Procter 2005; Meynhardt and Metelmann 2009).

In the light of NPM and PVM, and the importance of the middle manager, the following research question is of particular interest: Which antecedents explain the department-level entrepreneurial orientation of middle managers in the public sector? This article seeks to identify such antecedents, develop hypotheses, and provide empirical evidence for them. Our central argument is that - in addition to antecedents from private sector corporate entrepreneurship research - concepts discussed in NPM and PVM literature affect department-level EO in the public sector. Specifically, we include key performance indicator (KPI) focus and goal ambiguity — derived from the NPM literatureas well as a multitude of expectations and managers' localism - derived from the PVM literature.

We used data collected from multiple sources and levels of one of Europe's largest administrations, Germany's Federal Labor Agency, which recently defined increased entrepreneurial orientation (EO) as one of its primary reform goals (Meynhardt and Metelmann 2009, 278-80). Our findings contribute to a discussion in which it is sometimes asserted that quantifying public sector goals negatively affects organizational outcomes (Bevan and Hood 2006; Christiensen et al. 2007; Meynhardt and Metelmann 2009, 296-8; to some extent, also Pollitt and Bouckaert 2004). Our findings also support PVM scholars who argue for more networked governance, that is, governance that engages with different actors in the specific community (Kelly, Mulgan, and Muers 2002; Stoker 2006). In addition, corporate entrepreneurship research may benefit from validating established antecedents in a different context. In addition to implications for theory, specific indications for management will be outlined.

However, our findings' most interesting contribution is that they shift the attention from the more normative aspects of NPM and PVM to relating public sector entrepreneurship to the broader discourse on what drives EO in public organizations. Putting our quantitative study into a broader context, we follow Kelman, who called for public administration/public management to be closer connected "to the broader world of mainstream organization theory, which can help enrich our understanding of the public sector problems we study" $(2005,967)$. 


\section{BACKGROUND}

Entrepreneurship has been studied from a variety of perspectives by many scholars. As a result, certain concepts and terms used in entrepreneurship research are partly contradictory or overlap (Sharma and Chrisman 1999, 11). In this article, corporate entrepreneurship, as "the process whereby an individual or a group of individuals, in association with an existing organization, create a new organization or instigate renewal or innovation within that organization" (ibid, 18) will be used to refer to both the process and the literature on entrepreneurship within existing organizations. Public entrepreneurship will be used specifically for the public sector (Currie et al. 2008, 989). Entrepreneurial behavior will refer to how corporate entrepreneurship is practiced at an individual level (Kuratko et al. 2005, 699-700), whereas EO (Lumpkin and Dess 1996) will refer to an organization's or department's level of entrepreneurship, which will be characterized by innovativeness, risk taking, and proactiveness (Covin and Slevin 1991; Currie et al. 2008, 989; Miller 1983).

Both research and practice are interested in corporate entrepreneurship, which has been demonstrated to positively affect private sector organizations' performance (Covin and Slevin 1989; Lumpkin and Dess 1996; Rauch et al. 2009 for EO; Zahra 1991). Antecedents of corporate entrepreneurship have been researched intensively, and consensus has been reached on important variables (Zahra, Jennings, and Kuratko 1999). Empirically tested organizational antecedents of middle managers' entrepreneurial behavior include management support, work discretion, rewards/reinforcement, time availability, and organizational boundaries (Kuratko et al. 2005). More specifically, the perception of these antecedents (Marginson 2002) is relevant, that is, middle managers will act more entrepreneurially if they perceive top management as being supportive of such behavior (Hornsby et al. 2009). To a certain extent, the same holds true for environmental antecedents, such as perceived dynamism, technological opportunities, industry growth, and demand for new products (Antoncic 2007, 311).

Recent developments in public sector management have increased the need to understand how EO can be achieved in public administrations. Since the late 1970s, traditional public management (TPM), based on Weberian bureaucracy, has faced increasing criticism for inflexible structures, indifferent and bureaucratic staff, and overall unsatisfying performance (Schedler and Proeller 2006, 17-8; Hood 1991, 7). In response, the NPM approach — which seeks to improve management and processes by applying more private sector management techniques and market elements - was introduced (Schedler and Proeller 2006, 57; Hood 1991, 3-4). This shift also changed the public manager's role. It was thus assumed that the public manager's role would become similar to that of the private manager in that they were both to decide how best to achieve an outcome with a given amount of resources.

The introduction of NPM has realized some benefits, such as improved consumer orientation, clarification of objectives and responsibilities, and the use of executive agendas (Kelly, Mulgan, and Muers 2002, 9; Pollitt and Bouckaert 2004, 103-42). Despite these benefits, NPM reforms are also associated with negative developments in public management. In summarizing them, Kelly, Mulgan, and Muers $(2002,9)$ criticize NPM's allegedly narrow focus on measurable performance, which ignores what matters to the public, among others. In the view of PV advocates, this situation set the stage for reconsidering the public manager's role. Moore's book Creating public value: Strategic management in government (1995) - a plea for entrepreneurial management in the public sector with the ultimate goal 
of creating PV_ - initiated a nascent research field and management approach: public value management (PVM).

An elaborated comparison between TPM, NPM, and PVM is provided by Stoker $(2006,44)$ as well as Kelly, Mulgan, and Muers $(2002,10)$. The three approaches to public administration are very distinct in relation to public entrepreneurship. In Weberian-style TPM, there is little concern for entrepreneurship at the management level. In stressing one aspect of Weber's perspective, bureaucrats are expected to fulfill centrally (politically) set objectives and follow strict rules. Public participation is minimized; instead, managers must focus on internal procedures. NPM explicitly calls for entrepreneurship. The manager's role is more proactive: managers help determine targets, primarily by deciding on the appropriate means to achieve them. Entrepreneurship seeks to ensure performance in terms of efficiency and citizen/customer satisfaction. From an NPM perspective, a public servant should become like a private manager: "[A] good new public management system gives managers the freedom to manage. Politicians exist to set goals but then get out of the way" (Stoker 2006, 46).

Similarly to NPM, PVM calls for "entrepreneurial thinking" and decentralization. However, PVM requires a different type of manager. Instead of focusing purely on measurable performance, PVM expects managers to also maximize PV beyond efficiency goals (Moore 1995). Since this involves active engagement with all stakeholders and, above all, a sense for challenges and opportunities, the idea of entrepreneurship is explicitly directed to the notion of dialogue, facilitation, and co-production. This is not antithetical to NPM but is an additional role expectation at the heart of public entrepreneurship. Whereas NPM managers primarily focus on managing given tasks, PVM managers must leverage networks, access resources outside their domain (Stoker 2006, 41), and develop ideas with relevant actors across institutional boundaries (Meynhardt 2008, 459). The manager's task thus also includes managing the network and considering public opinion through dialogue. This is not the main focus on NPM's agenda.

In contrasting the two views of public entrepreneurship (a more narrow one in NPM and a broader one in PVM), it becomes clear that stimulating entrepreneurial activity is not per se equivalent to creating PV. In some instances, NPM-oriented entrepreneurial behavior might even destroy PV, for example, via a short-term focus on performance measurement or a one-sided trade-off between fiscal stress and social stress. Although NPM and PVM both require entrepreneurship, they focus on different aspects.

As already mentioned, despite its increasing importance, public entrepreneurship has been the subject of little research. Research on heroic managers at the top of organizations (Lewis 1980; Osborne and Gaebler 1992) has long dominated the debate, whereas research on other actors is only slowly developing. Yet, various studies have identified public middle managers - the managers between frontline managers and top managers (Rainey 1983, 215) - as crucial to public entrepreneurship. In the private sector, middle managers communicate new initiatives to top management (Burgelman 1983a, 1983b), promote autonomous and informal entrepreneurship (Kanter 1985, 1989), and generally shape an organization's strategy by championing proposals and programs, by synthesizing information, by facilitating adaptability, and by implementing deliberate strategy (Floyd and Lane 2000; Floyd and Wooldridge 1997). In the public sector, Morris and Jones $(1999,83)$ find that middle management represents the most entrepreneurial management sector; Borins $(2000,500)$ identifies middle managers as by far the largest group of 
initiators; Bernier and Hafsi $(2007,494)$ describe them as the main source of creativity in public entrepreneurship; and Burgelman (1985, 595-6) asserts that, like corporate entrepreneurs, public entrepreneurs can be found "deep in the organization" rather than at the top.

Most studies on public entrepreneurship apply either a purely conceptual approach (Bellone and Goerl 1992; Kearney, Hisrich, and Roche 2008; Ramamurti 1986) or rely on own experience and anecdotal evidence (Bernier and Hafsi 2007; Lewis 1980; Moore 1995; Osborne and Gaebler 1992; Roberts and King 1991). Few studies apply a rigorous approach to conducting case studies (Currie and Procter 2005; Meynhardt and Metelmann 2009; Zerbinati and Souitaris 2005). Those studies that use quantitative data either remain descriptive (Borins 2000; Morris and Jones 1999) or completely neglect middle managers (Kim 2007; Mack, Green, and Vedlitz 2008; Moon 1999; Schneider, Teske, and Mintrom 1995; Teske and Schneider 1994; Wood et al. 2008). Overall, there appears to be a general lack of detailed studies and rigorous theory testing in public entrepreneurship research (this interpretation is in line with Zerbinati and Souitaris 2005, 46; Currie et al. 2008, 988; Morris and Jones 1999, 87). Prior studies provide important indications, which are used to develop an integrated model in the next section.

\section{THEORETICAL MODEL}

With the emergence of NPM and PVM, there has been an increase in the demand for entrepreneurial behavior and orientation in public sector organizations. New public management relies on the explicit assumption that private sector concepts can and should be transferred to the public sector. With regard to entrepreneurship, there are, however, chances for and limits to transfer: private sector research may provide antecedents that can be applied independently by a sector, such as management support or resource availability. On the other hand, a public organization is not mandated to seek profits but required to fulfill its politically defined tasks. The financial bottom line is just one aspect among others, such as social cohesion, fairness, or justice. Very similar to entrepreneurship in a corporation, risk orientation and innovation can only apply in areas with discretion and a mandate to actively create something new - here, for example, shaping urban development, social work, and labor market services. In public organizations where strict reliability is essential, such as payment services and public safety, rule-based behavior is needed, not entrepreneurship. In our study, we will incorporate and deliberately yet cautiously adapt organizational antecedents from private sector research. Despite the difficulties involved, we seek to empirically test organizational antecedents since private sector concepts may build on more fundamental principles of human behavior that are not restricted to any sector.

Nevertheless, the discussion on NPM and PVM has shed light on additional antecedents that are particularly interesting in the public sector context. Figure 1 illustrates our conceptual model. This model and the following hypotheses are based on three assumptions. First, for middle managers to act in a certain way, their perception of an antecedent is more important than its actual existence (Marginson 2002). Second, this study assumes that middle managers' entrepreneurial behavior - a core aspect of corporate entrepreneurship (Hornsby, Kuratko, and Zahra 2002; Hornsby et al. 2009; Kuratko et al. 2005) - has a direct impact on their department's EO (Pearce, Kramer, and Robbins 1997). Third, and perhaps most importantly, EO is not detrimental to an administration's legal mandate, that is, through EO, value is created and not destroyed. We therefore empirically investigate the relationship between EO and an orientation toward PV creation. 
Figure 1

Conceptual Model Including Summary of Hypotheses

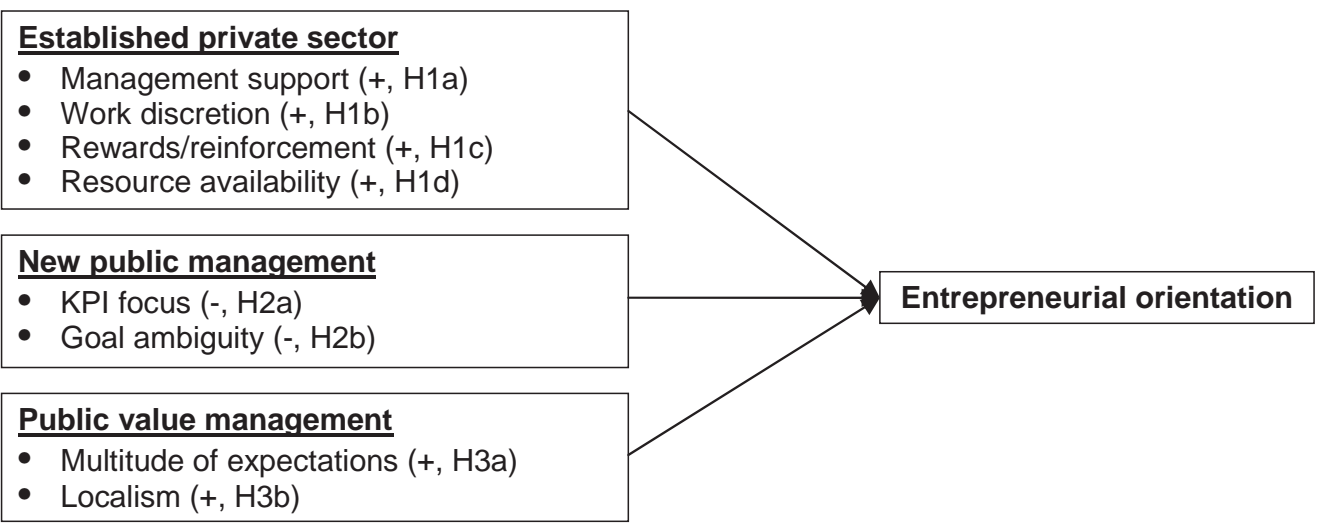

Note. Parentheses contain expected direction of effect and hypothesis number.

\section{Antecedents Derived from Private Sector Literature}

With regard to the private sector, scholars (e.g., Hornsby et al. 2009; Kuratko et al. 2005) have recently used a fairly stable set of organizational antecedents. This set is based on work by Hornsby, Kuratko, and Zahra (2002), who have developed and tested an instrument assessing organizational antecedents that influence middle managers, based on an extensive literature review (see Hornsby, Kuratko, and Montagno 1999, 11) and a number of empirical tests. They have identified the perceptions of management support, work discretion, rewards/reinforcement, time availability, and organizational boundaries as relevant (Hornsby, Kuratko, and Zahra 2002, 261). We use this structure to discuss the impact of established organizational antecedents from private sector literature.

In this article, management support is defined as the extent to which one perceives that superior managers support, facilitate, and promote entrepreneurial behavior (adapted from Hornsby et al. 2009, 238). This can take on a number of forms, including championing or adopting innovative ideas, recognizing employee ideas, supporting small projects, providing expertise, and institutionalizing entrepreneurial activity within the organization's system and processes (Hornsby et al. 2009, 238; Hornsby, Kuratko, and Zahra 2002, 259; Hornsby et al. 1993, 32; Kuratko et al. 2005, 703). In the public sector as much as in the private sector, middle managers are more likely to behave entrepreneurially when they perceive support for such behavior. In contrast, middle managers are less likely to behave entrepreneurially when superior managers discourage innovative, proactive, and risktaking behavior. Therefore:

H1a: Public middle managers' perception of management support positively relates to their department's EO.

In this article, work discretion is defined as superior managers' commitment to "tolerate failure, provide decision-making latitude and freedom from excessive oversight, and to delegate authority and responsibility to middle-level managers" (adopted from 
Kuratko et al. 2005, 704). Work discretion is provided when middle managers have the leeway to decide on how to most effectively perform their work. Such discretion can be achieved if middle managers are not punished or criticized for making mistakes while being innovative (Hornsby et al. 1993, 32). In the public sector as much as in the private sector, middle managers are more likely to behave entrepreneurially when they perceive discretion in their work. Managers who are encouraged to decide how to achieve goals will find more creative ways of doing so. They are more likely to experiment and innovate when fewer strict rules and procedures are in place. What is specific to the public sector is the areas in which, and the extent to which, discretion is appropriate. In certain cases, centrally determined or legally binding goals and procedures are inevitable. In many other cases, work discretion will allow managers to behave more entrepreneurially. Therefore:

H1b: Public middle managers' perception of work discretion positively relates to their departments' EO.

In this article, the term rewards/reinforcement is defined as "systems that reward based on performance, highlight significant achievements, and encourage pursuit of challenging work" (Kuratko et al. 2005, 703). With respect to EO, employee perceptions of the extent to which the organization offers reward systems that honor entrepreneurial activity and success are crucial (Kuratko et al. 2005, 701, 709). Examples of rewards/reinforcement include increased responsibility, monetary incentives, recognition through badges or ceremonies, and disseminating innovative people's ideas (e.g., Sathe 1989, 26; Hornsby et al. 1993, 32; Kanter 1985, 55). Many of these forms are also available to the public sector (for associated difficulties, see Markowski and Hall 2007, 273).

The concept of rewards/reinforcement is considered an important antecedent of EO because entrepreneurial behavior is associated with personal risks, such as career derailment in the case of failure (Kuratko et al. 2005, 701). Appropriate rewards and reinforcement can motivate employees to engage in entrepreneurial behavior by offsetting such risks (Hornsby, Kuratko, and Zahra 2002, 259; Hornsby et al. 1993, 32). In other words, if entrepreneurial behavior is not rewarded or recognized, there is little extrinsic incentive to engage in the risky endeavor of entrepreneurship.

A number of empirical studies in related fields indicate the importance of rewards/ recognition. Hisrich and Peters (1986) find evidence for performance goals and appropriate reward systems as antecedents of successful new business venture units. Morris and Jones (1993) discover that more entrepreneurial companies reward individual performance, focus on long-term outcomes, and explicitly encourage entrepreneurial behaviors. Wood et al. $(2008,126)$ provide initial evidence of a positive correlation between the appropriate use of rewards and corporate entrepreneurship in their study with military and civilian employees of the US Air Force. Therefore, we hypothesize a relationship that is similar to that in the private sector:

H1c: Public middle managers' perception of rewards/reinforcement positively relates to their departments' EO.

In this article, resource availability is defined as the perceived "availability of resources for innovative activities" (Hornsby, Kuratko, and Zahra 2002, 253) including financial resources, time availability, and human resources. Covin and Slevin $(1991,15)$ also use such a broad definition of resources (including monetary resources, fixed assets, and human resources) as an antecedent to corporate entrepreneurship. In contrast to the concept of 
"slack resources," which refers to excess resources (Cyert and March 1992, 42), here, "resource availability" refers to the accessibility of resources. In the public sector as much as in the private sector, middle managers who perceive available resources for innovative activities are more likely to experiment and take risks (Hornsby, Kuratko, and Zahra 2002, 253). In the public sector, financial resources will be relevant in terms of budget flexibility. The absolute budget amount is less relevant since it is determined by means of a political process in which middle managers are not involved. With such flexibility, middle managers can quickly provide seed funding for initiatives. However, financial resources are not enough. Managers need time to oversee, develop, and enhance experiments. In the end, sufficient human resources are key_initiatives can be launched much more easily if they receive support from motivated, innovative employees. Therefore, a relationship similar to that in the private sector is hypothesized:

H1d: Public middle managers' perception of resource availability positively relates to their departments' EO.

\section{Antecedents Derived from New Public Management Literature}

NPM reforms have increased the focus on measurable results in many organizations (Pollitt and Bouckaert 2004, 90). The diverse effects of management control systems (MCS) are also recognized in the public sector (Kearney, Hisrich, and Roche 2008, 303). This study focuses on the two particularly prominent aspects of MCS: KPI focus and goal ambiguity.

In this article, KPI focus is defined as the extent to which one perceives that superior managers manage by means of KPIs. KPI focus thus describes how much focus managers place on the quantifiable aspect of management by objectives (MbO) (Drucker 1993, 119-34). In the public sector, $\mathrm{MbO}$ at the organizational level is also referred to as governance by targets (Bevan and Hood 2006). Excessive control (Sykes 1986, 277-8) and formal control (Zahra 1991) can have negative effects on corporate entrepreneurship in the private sector. However, evidence is contradictory. Barringer and Bluedorn (1999) find no effect of financial control on corporate entrepreneurship; and Marginson (2002, 1026) finds no effect of KPI use that discourages the development of initiatives and new ideas. In the NPM context, the implementation of tools that measure output/outcome has evoked mixed reactions. On the one hand, KPIs have helped public organizations focus and improve their customer orientation. This was possible due their increased role in management, for example, as a basis for decisions, benchmarking, and/or budgeting (Pollitt and Bouckaert 2004, 92). Depending on how goals are set, they can also inspire middle managers to develop and implement their own creative, entrepreneurial ways to achieve goals (Marginson 2002, 1025).

On the other hand, the stronger focus on quantifiable measures is being criticized for producing unintended consequences, such as neglecting important nonquantifiable aspects and fostering tunnel vision (Pollitt and Bouckaert 2004; Smith 1995). We hold that a strict focus on only formal controls (in this case KPIs) may restrict the leeway for entrepreneurial behavior and distract attention away from innovative action. Therefore,

H2a: Public middle managers' perception of the extent of KPI focus negatively relates to their departments' EO. 
In this article, goal ambiguity is defined as the extent to which organizational goals are perceived as ambiguous and numerous (adapted from Ramamurti 1986, 150). Specifically, here, organizational goals refer to personally relevant objectives (versus organizational goals). As the term suggests, goal ambiguity is the opposite of goal clarity (Pandey and Garnett 2006, 38). Public middle managers appear particularly prone to role conflicts. On the one hand, middle managers are generally said to experience particularly high levels of role conflict (Floyd and Lane 2000). On the other hand, in public sector organizations, goals are particularly vague, intangible, numerous, and conflicting (Rainey 2009, 149). Consistent with these observations, Currie and Procter (2005) find that role conflicts prevent hospital middle managers from taking a strategic role. Meynhardt and Metelmann (2009) find evidence that middle managers' role conflicts arise from the multidimensional nature of the task itself and less so from the natural sandwich position between top management and frontline management. With regard to public entrepreneurship, goal ambiguity's role is unclear; although several scholars consider it beneficial, others consider it an obstacle to public entrepreneurship. Ramamurti (1986, 151), for example, identifies goal ambiguity as one of six "well-known" barriers to public entrepreneurship since conflicting goals could paralyze managers. However, he also points out that entrepreneurial managers can deal with conflicts and use undefined areas to broaden organizational tasks. Acknowledging opposing views, we hypothesize along the same lines as Floyd and Lane (2000), Currie and Procter (2005), and Meynhardt and Metelmann (2009). Numerous, contradictory, and complex organizational goals will increase middle managers' role conflicts, impeding them from taking a more strategic and entrepreneurial role. Therefore,

$H 2 b$ : Public middle managers' perception of goal ambiguity negatively relates to their departments' EO.

\section{Antecedents Derived from Public Value Management Literature}

The PVM approach is very different from the NPM approach. In PVM, the local environment and stakeholders are supposed to be involved in dialogues and decision making. The manager's role is to engage with these networks and to consider a multitude of individual and public expectations. A new focus is also proposed with respect to the democratic process: it is based on extended dialogue on the public dimension and public interest. Moore's basic idea is to mobilize different actors in a community to engage with the process of public deliberation and social problems that cannot be solved by just one party. He, together with Bennington, therefore draws on Dewey's argument to "call into existence a public that can understand and act on its own best interests" (Bennington and Moore 2011, 273). Despite this participative element of explicitly facing the ever-changing needs in the public sphere and co-production being a basic tenet within the PV discourse, none of the constructs has as yet been measured. Here, we focus on the multitude of expectations and manager localism.

In this article, multitude of expectations is defined as the perceived variety and diversity of external local actors' expectations. Local actors, such as employers' associations, trade unions, local authorities, politicians, and welfare institutions, are vocal groups in society that affect middle managers in some way. Acknowledging existing needs, sensing potential synergies and conflicts may be seen as a prerequisite for effective entrepreneurship. The construct multitude of expectations thus includes the perceived key stakeholders' 
expectations (Currie and Procter 2005) and involvement and dialogue in networks (Stoker 2006). The more diverse the local actors' expectations, the more creative managers will have to be to abandon, influence, or fulfill these expectations. In contrast to internal organizational goals (H2b), managers are not obliged to fulfill all external expectations. Instead, a manager can and must balance or even deprioritize inappropriate expectations and use others as an inspiration to identify opportunities not evident from within the organization. However, this constant exposure to external voices should have a positive impact on EO. Therefore,

H3a: Public middle managers' perception of a multitude of expectations positively relates to their departments' EO.

In this article, we define localism as middle managers' willingness and desire to fulfill the local community's needs. Following Roof, localism is a measure of communal reference and denotes "an individual's scale of social experience and participation" (1972, 3-4). At the individual level, the phenomenon will, for example, be reflected in a sense of feeling at home in a given district, participation in voluntary work, or in a need for appreciation in the local community. In contrast to Roof (1972), who conceptualizes localism as part of the dichotomy localism versus cosmopolitanism, localism is seen as unipolar here. In an early work on corporate entrepreneurship, Sathe (1988) emphasizes the need to develop managers who possess profound knowledge of relevant areas and underlines the need for personal external contacts and networks. With regard to the public sector, Mack, Green, and Vedlitz (2008) find public entrepreneurship not only to positively correlate with the number of local social/service organization memberships and to positively correlate with a preference for local community but also to negatively correlate with memberships in local business organizations. Schneider, Teske, and Mintrom (1995) conclude that public sector entrepreneurs are motivated by their desire to respond to the local community's needs and local politics. They also characterize public sector entrepreneurs as embedded in social networks. This embeddedness helps them discover opportunities and find support to implement ideas (Schneider, Teske, and Mintrom 1995, 216). Similarly, Mintrom $(2000,282)$ identifies the importance of networking for policy entrepreneurs to succeed. He points out that entrepreneurs can earn stakeholder trust and learn their preferences. Social capital (Coleman 1988), which Floyd and Wooldridge (1997) identify as an important antecedent of organization members to act entrepreneurially, is thus an important part of localism and the logic behind its influence on EO. Middle managers can exchange information with local stakeholders and fulfill or facilitate their needs. However, middle managers will be more likely to do so if they do have the desire to create value for local communities. These interrelated characteristics are combined in the following hypothesis:

$H 3 b$ : Public middle managers' degree of localism positively relates to their departments' EO.

\section{METHODS}

\section{Context: Germany's FLA}

To evaluate our hypotheses, we used department-level aggregated data collected during a larger research project on PVM at Germany's FLA. In-depth studies of single 
organizations have repeatedly been called for by corporate entrepreneurship scholars (e.g., Zahra, Jennings, and Kuratko 1999, 55; Morris et al. 2006, 488), and the FLA appears especially suited. Founded in 1927, the FLA employed 113,000 people in 2010. It offers employment services and coordinates transfer payments. NPM reforms have been introduced in recent years to increase efficiency and EO (Meynhardt and Metelmann 2009, 280). The reforms and the FLA's cultural context (active in a Rechtsstaat; Pollitt and Bouckaert 2004, 42) have made it a role model for other European countries, such as France.

The FLA's organizational structure includes headquarters in Nuremberg as well as 10 regional offices across Germany. At the local level, 178 agencies (German: Arbeitsagenturen; hereafter referred to as departments) perform the operational tasks to fulfill the FLA's legal mandate. Although strategy is determined centrally, strong regional differences in the labor market require adaptations, resulting in regional differences in the interpretation and application of central directives. A MbO approach ensures adherence to the general policies and budget constraints set by the government. At the same time, this approach provides degrees of freedom to effectively and efficiently use resources to comply with regional conditions (e.g., municipality versus rural areas). This is where the idea of entrepreneurship comes into play. Bound by the legal mandate and to objectives annually agreed on by the headquarters, the local agencies are inspired to achieve their results in an entrepreneurial way.

To ensure comparability among departments, the FLA uses five strategy groups. Departments in the same group exhibit similar labor market conditions and are therefore comparable. ${ }^{1}$ The departments are directed by three types of middle managers (hereafter referred to as department managers): local agency heads, local operations heads, and local internal services heads. Department managers have one of three types of contracts: traditional lifelong civil servant contracts, civil servant contracts that are temporarily suspended in order to use other HR measures (hereafter, civil servants on leave), and regular employee contracts.

In short, the FLA setup seems well suited for this single case research. It is a public sector organization that demands entrepreneurial behavior from its middle management. All of its 178 departments fulfill the same legal mandate, but vary in important aspects, including EO. Thus, a comparison - as anticipated by Morris et al. (2006, 488) - seems possible. It should be noted that EO is not equally relevant in all parts of the FLA's business. Kelly, Mulgan, and Muers (2002, 34-5) recognize that value in public sector organizations is created through entrepreneurial behavior in some areas but through adherence to standards in others. Entrepreneurship is considered important in the fragmented labor market, where local characteristics and a fast-changing environment require entrepreneurial responses. However, this is not true for the FLA's task of coordinating transfer payments, which is therefore explicitly excluded from this study.

1 Strategy group I: urban, low unemployment; group II: urban, high unemployment; group III: rural, high unemployment; group IV: rural, low unemployment; group V: mostly eastern part of Germany, high unemployment (Dauth, Hirschenauer, and Rüb 2008). 


\section{Data Collection and Sample Data}

We used online questionnaires to collect data from our key respondents, namely the department managers, who provided data on the antecedents and our dependent variable department-level EO. In addition, department-level EO was assessed by the managers' supervisors, the heads of regional offices. A number of tactics were applied to increase key respondent participation, including a personalized announcement letter signed by a board member, a detailed privacy policy, and a reminder email (Simsek and Veiga 2000, 107-8). Using personalized links, the FLA survey unit enriched the survey data with demographics.

Of the 347 department managers (including all three types), we successfully contacted 343, of whom 264 participated. Following a conservative approach, we excluded 13 cases from the analyses due to missing values in the dependent variable EO (Hair et al. 2010, 48) and 1 case for missing more than $20 \%$ of all other variables (following Antoncic and Hisrich 2001, 56, who use $25 \%$ as a cutoff point). For the remaining 250 cases, Little's MCAR test indicates data missing completely at random, thus allowing any method to be used to impute data (Hair et al. 2010, 56-60; Rubin 1976). Using expectation maximization, we replace 84 values, representing $0.7 \%$ of all values used in the subsequent analyses. Using these data, the effective response rate is $73 \%$ at the department manager level ( 250 of 343 ) with responses from $85 \%$ of the departments. More specifically, the 250 questionnaires are from 152 departments, of which 65 provided one, 76 provided two, and 11 provided three questionnaires. The department managers included in the analyses are on average 50.6 years old, have a 23.3-year organization, 6.3-year department, and 4.3-year position tenure; most are civil servants $(55 \%)$, followed by civil servants on leave $(22 \%)$, and employees (22\%; reported values exclude missing data). We see little reason to assume nonresponse bias. First, the response rate-73\% - is high. Second, no variable in the final model is correlated with the recorded order of survey completion (Armstrong and Overton 1977, 397; Kanuk and Berenson 1975, 449). Third, respondents and nonrespondents only differ in terms of their department's size, with no differences in gender, function, region, or strategy group.

To mitigate the potential for common method bias, we followed a number of procedural techniques (e.g., randomly rotating items within constructs, ensuring anonymity, and encouraging honest answers) and statistical techniques (Podsakoff et al. 2003, 887; Churchill 1979, 70). Harman's single-factor test using unrotated factor analysis resulted in 24 factors with eigenvalues greater than one. The first factor explained less than $15 \%$ of the variance in the data and consequently does not indicate a common method bias (Podsakoff and Organ 1986, 536). In addition, up to three department managers rated their own department's EO; in 62 cases (41\%), their regional office supervisor also rated this department's EO using questionnaires with identical wording. To assess the reliability of our key respondents (department managers), we calculated two-way intraclass correlation coefficients ICC(C,1) (James 1982). ICC(1) values of .25 are considered large (Cohen 1988 , 79-81), indicating that a single rating is likely to provide a reliable rating of the group mean (Bliese 2000, 356). The average $\operatorname{ICC}(\mathrm{C}, 1)$ between the supervisor ratings and department-level aggregated self-reports is .46 for all 62 departments. ICC even reaches .80 for supervisors indicating maximum familiarity with a department. We therefore use department-level aggregated data from our key respondents (department managers) from here onward. 


\section{Measures}

All constructs were measured using multiple items on a six-point Likert-like scale, using adaptations from existing literature where possible. Since there are few public sectorspecific scales available, modifications were made to existing items. For these modifications and the creation of new items, we followed recommended scale development steps (e.g., Hinkin 1995). As a result, we created an initial item pool based on construct definitions, designed scales, and conducted qualitative and quantitative pretests. In the qualitative pretesting, we involved 13 FLA experts, 7 academics, and the FLA's top management by means of workshops, mail correspondence, as well as personal and telephonic interviews. The questionnaire was then pretested quantitatively on a random sample of 40 FLA department managers (78\% response rate). Additional adjustments were made and discussed with FLA managers before launching the survey.

\section{Antecedents}

We used items from the Corporate Entrepreneurship Assessment Instrument (CEAI; Hornsby, Kuratko, and Zahra 2002, 254) as a basis to measure management support, work discretion, rewards/reinforcement, and resource availability. Several aspects of the CEAI were judged unsuitable during the qualitative pretest in the FLA context for reasons of content and language. We therefore adapted CEAI items or created new items. To measure goal ambiguity, items were adapted from existing scales for goal clarity (Pandey and Garnett 2006, 42; Rainey 1983) and role conflict (Rizzo, House, and Lirtzman 1970, 237). No adequate scales could be found for KPI focus and multitude of expectations. For localism, existing items were adapted (Mack, Green, and Vedlitz 2008, 244) and new items were created based on definitions (Roof 1972). Table A1 contains a list of all items.

\section{Entrepreneurial Orientation}

Although, in the private sector, a reliable and valid EO measure has been developed over the past 30 years, no equivalent measure has been found for the public sector. EO-defined according to the three dimensions of innovation, proactiveness, and risk-taking - has mostly been measured by the ENTRESCALE (Covin and Slevin 1989; Miller 1983) or one of its derivatives. Yet, existing scales are largely inappropriate for the public sector due to their strong market focus (e.g., "In dealing with its competitors, my firm typically seeks to avoid competitive clashes, preferring a 'live-and-let-live' approach"; Covin and Slevin 1989, 86). The risk-taking dimension has proven to be the least sector-specific. Morris and Jones $(1999,87)$ argue along the same lines and identify a need to adapt existing private sector EO measures to public sector particularities. A recent meta-analysis shows that careful modifications of Covin and Slevin's scale did not compromise its validity. The authors even encourage such adaptations (Rauch et al. 2009, 778-9). As a result, new items for the innovation and proactiveness dimensions were created and existing items were adapted for the risk-taking dimension. 


\section{Control Variables}

Department characteristics controlled for were number of employees (de Clercq, Dimov, and Thongpapanl 2010, 95; Zahra, Jennings, and Kuratko 1999, 54) and strategy group (de Clercq, Dimov, and Thongpapanl 2010, 95 use industry; Hornsby et al. 2009; Zahra, Jennings, and Kuratko 1999, 54). With regard to the department management team, we included type of contract, age, as well as tenure in current position and current department (one variable computed as the minimum of the two separate questions about tenure), as well as tenure in the organization (Hornsby et al. 2009; Hornsby, Kuratko, and Zahra 2002, 263). To mitigate the problem of nonnormality while ensuring comparability, we used the log of the size, tenure, and age variables. Categorical variables were dummy coded for the analyses.

\section{Measurement Reliability and Validity}

Before conducting our focal analyses, we established unidimensional, reliable, and valid measures. To do so, we applied exploratory factor analysis (EFA) and confirmatory factor analyses (CFAs). An EFA (common factor analysis) with orthogonal rotation (varimax) (Hair et al. 2010, 105-8) was applied to all independent variable items. As shown in table A2, the results indicate clean loadings for resources, KPI focus, goal ambiguity, and localism. To ensure unidimensional, reliable, and valid measures for all constructs, we refined the measurements by means of CFA. As suggested by Hair and colleagues (2010, 676), we used the following indicators (and generally accepted thresholds) to judge the fit of our models: $\chi^{2}$ /associated $\mathrm{df}(\leq 3.00)$, root mean square error of approximation (RMSEA) $(\leq .08)$, standardized root mean square residual (SRMR) $(\leq .10)$, comparative fit index (CFI) ( $\geq .90)$, and Tucker-Lewis index (TLI) ( $\geq .90)$. After removing insignificant items and items with high modification indices, the model demonstrated an acceptable fit. During this process, the constructs management support and work discretion were combined as they could not be differentiated according to the data; furthermore, the measurement for rewards/reinforcement could not be established as its items loaded on more than one factor. The EO measure was established using the three dimensions risk-taking, innovativeness, and proactiveness as latent variables, applying CFA. After deleting four problematic items, we accepted the EO measurement model, with all indices achieving optimal values. We also ran CFA for the entire measurement model, including the independent variables. The resulting model showed acceptable fit: $\chi_{(314, N=152)}^{2}=406.43, p=$ $.00, \chi^{2} / \mathrm{df}=1.29, \mathrm{RMSEA}=.04, \mathrm{SRMR}=.06, \mathrm{CFI}=.95, \mathrm{TLI}=.94$. Table A3 and figure A1 contain the model specifications and fit indices for all models.

We assessed reliability (convergent validity, Fornell and Larcker 1981, 46) at the item and construct levels. At the item level, all loadings are significant at $p<.001$. At construct level, all constructs reached the ideal value of $>.60$ for composite reliability (Bagozzi and Yi 1988, 80): management support/work discretion (0.86), resource availability (0.71), KPI focus (0.89), goal ambiguity (0.68), multitude of expectations (0.67), localism (0.65), innovativeness $(0.88)$, proactiveness $(0.80)$, and risk taking $(0.81)$. The average variance extracted is below the desirable level of $>.50$ for four constructs, indicating that less variance was explained in these constructs by their measures than not (Fornell and Larcker 1981, 46; Bagozzi and Yi 1988, 80). To prevent jeopardizing content validity, we continue our analyses with the four constructs resource availability (0.46), goal ambiguity $(0.43)$, multitude of expectations (0.43), and localism (0.39), acknowledging that the measures are 
not perfectly reliable. Discriminant validity was assessed following the procedure suggested by Fornell and Larcker (1981). As required, most constructs' average variance extracted (AVE) is larger than the squared correlations $\left(R^{2}\right)$ with other constructs. Only proactiveness's $A V E$ of .57 is smaller than its $R^{2}$ with innovativeness (.66). Given that the two dimensions are combined to represent EO, this marginal violation seems uncritical.

\section{External Validity}

There are four elements of empirical evidence that — in our view — strengthen the results' generalizability within the FLA. The first is the combination of a high response rate and little indication of biases due to nonresponse or missing data (population validity) (Bracht and Glass 1968, 438).

Second, we do not rely entirely on the middle managers' self-assessment of EO with regard to how innovative, proactive, and risk taking their departments are. Instead, we find a high consistency between middle managers' assessments and their supervisor's assessment (see the section Data Collection and Sample Data). Supervisors and middle managers thus basically agree on which departments are entrepreneurial. Furthermore, the participants also supplied behavioral-level data, that is, the frequency of initiatives launched in their departments. In defining these initiatives in the questionnaire, we focused on initiatives that go beyond the usual daily business. Within the statutory mandate, these initiatives create PV for the district not entirely measurable in numbers and data. Our dependent variable EO correlates significantly with this frequency $(r=.39, p<.001)$, thus indicating that our dependent variable has a positive PV-creating capability.

Third, a number of FLA projects provide observable evidence for FLA middle managers' possibilities and entrepreneurial activities. One such project is the fair Meer Arbeit, which specializes in cruise ship crew job placements. The fair was initiated by the FLA agency in Suhl, an inland city. Today, Meer Arbeit operates a competence center for maritime jobs. Owing to this and other initiatives, Suhl's unemployment rate is among the lowest in Eastern Germany (Bundesagentur für Arbeit 2011; Tietz 2008). Another project is Bürgerarbeit (civic work), in which unemployed people are provided with community jobs. The model is currently implemented at a federal level after it was originally tested in the town of Bad Schmiedeberg (Spiegel Online 2010; Steiner et al. 2008). Both projects were initiated by middle managers, have required innovativeness, proactiveness, and risk taking, and have had long-term effects beyond the local context.

Fourth, after the analyses, we discussed our findings in two workshops (with about 25 survey participants each). The workshop participants confirmed our findings and interpretations. We therefore hold that there is a good fit between our findings and the FLA context.

In addition, we conducted one final validity test, somewhat independently from the previous aspects. We determined the correlation between our dependent variable EO and a desirable organizational outcome relevant to fulfilling the legal mandate. In the middle manager questionnaire, we included items on the departments' PV orientation (e.g., "My department, compared to other departments ... contributes sustainably to public value" and “... creates public value beyond figures and data within the legal mandate"). The department-level self-reported EO and public value orientation scores are significantly correlated $(r=.56, p<.001)$, thus indicating that EO is not detrimental to the FLA's legal mandate. 


\section{ANALYSIS AND FINDINGS}

Table 1 reports descriptive statistics and Pearson correlations of all control variables and composites based on the final CFA model. Values for our dependent variable - the EO score - range from 1.56 to 6.00 with a mean of 4.08, a standard deviation of .66, a mode of 4.00, and a median of 4.00. Again, these data are from the department level, aggregated from department managers. We used a hierarchical ordinary least squares regression analysis with forced entry to test our hypotheses. Inspections of the data do not indicate problems for our regression results (table 2) in terms of multicollinearity, nonnormality, heteroscedasticity, nonlinear relationships, outliers, or nonindependent errors.

Model 1 contains control variables for department characteristics. These antecedents do not significantly explain EO variance. In Model 2, we include the control variables relating to the department management team and explain an additional $13 \%$ of the variance. The dummy variables for contract type indicate that departments with more employees display a higher EO. Moreover, departments with managers that have longer tenure in their current position in their current department are more entrepreneurially oriented. Model 3 contains all control variables and the antecedents derived from established private sector literature. The inclusion of these variables significantly improves the model, explaining an additional $7 \%$ of EO variance. As expected, management support (H1a), work discretion (H1b), and resources (H1d) positively and significantly impact EO. Model 4 includes the antecedents derived from NPM/PVM research. This further improves variance explanation by $14 \%$, resulting in an $R^{2}$ of $41 \%$. KPI focus is not significant (H2a) but only by a small margin. In fact, KPI focus's impact is in the opposite direction than originally hypothesized. Departments with a strong perceived focus on KPIs are more likely to be entrepreneurially oriented. Goal ambiguity (H2b) is clearly insignificant. Both antecedents derived from the PVM literature are significant. Consistent with $\mathrm{H} 3 \mathrm{a}$ and $\mathrm{H} 3 \mathrm{~b}$, a multitude of expectations and localism positively impact EO. In Model 4, current position/department has the highest significance level, followed by expectations, contract (employee), strategy group (IV), localism, and resources. Management support/work discretion is no longer significant at the $5 \%$ level. In short, the selected antecedents help explain much of the departments' EO; specifically, $41 \%$ of the variance can be explained. Additional robustness tests at an individual level and by means of structural equation modeling confirm the results.

In summary, we find support for two of the three main hypothesis groups. Owing to the strong correlations between the items of established private sector antecedents, only a combination of management support, work direction, and resources could be tested. As expected, these are positively correlated with EO in Model 3, providing some support for H1a, H1b, and H1d. Yet, in Model 4, management support/work discretion is no longer significant. H1c, suggesting a positive effect of rewards/reinforcement on EO, could not be tested. $\mathrm{H} 2 \mathrm{a}$ and $\mathrm{H} 2 \mathrm{~b}$, suggesting negative impacts of KPI focus and goal ambiguity on EO, could not be confirmed. Finally, we find support for $\mathrm{H} 3 \mathrm{a}$ and $\mathrm{H} 3 \mathrm{~b}$, concerning the positive effects of multitude of expectations and localism on EO. The strong positive impact of tenure in position/department on EO is also noteworthy for the following discussion. 
Table 1

Descriptive Statistics and Pearson Correlations

\begin{tabular}{|c|c|c|c|c|c|c|c|c|c|c|c|c|c|c|c|c|c|c|}
\hline Variables & Mean & $\mathrm{SD}$ & 1 & 2 & 3 & 4 & 5 & 6 & 7 & 8 & 9 & 10 & 11 & 12 & 13 & 14 & 15 & 16 \\
\hline $1 \mathrm{EO}$ & 4.08 & 0.66 & & & & & & & & & & & & & & & & \\
\hline 2 Department size $(\log )$ & 2.47 & 0.24 & -.02 & & & & & & & & & & & & & & & \\
\hline 3 Strategy group II $^{\mathrm{a}}$ & 0.14 & 0.35 & -.10 & $.39 * * *$ & & & & & & & & & & & & & & \\
\hline 4 Strategy group III ${ }^{\mathrm{a}}$ & 0.24 & 0.43 & -.07 & $-.16^{*}$ & $-.22 * *$ & & & & & & & & & & & & & \\
\hline 5 Strategy group $\mathrm{IV}^{\mathrm{a}}$ & 0.26 & 0.44 & $.25 * * *$ & $-.28^{* * *}$ & $-.24 * *$ & $-.33 * * *$ & & & & & & & & & & & & \\
\hline 6 Strategy group $\mathrm{V}^{\mathrm{a}}$ & 0.20 & 0.40 & -.08 & .10 & $-.20 *$ & $-.28 * * *$ & $-.30 * * *$ & & & & & & & & & & & \\
\hline 7 Employee $^{\mathrm{a}}$ & 0.20 & 0.33 & .08 & .02 & -.05 & .05 & -.14 & .06 & & & & & & & & & & \\
\hline 8 Civil servant on leave ${ }^{a}$ & 0.22 & 0.34 & -.06 & .03 & -.03 & -.04 & -.05 & .03 & $-.21 * *$ & & & & & & & & & \\
\hline $\begin{array}{l}9 \text { Position/departmental } \\
\text { tenure }(\log )\end{array}$ & 0.58 & 0.22 & $.33 * * *$ & -.02 & -.10 & -.06 & .12 & .05 & $-.21 * *$ & -.15 & & & & & & & & \\
\hline $\begin{array}{l}10 \text { Organization tenure } \\
(\log )\end{array}$ & 1.32 & 0.18 & .11 & .01 & .07 & .01 & $.17^{*}$ & $-.26^{* * *}$ & $-.45^{* * *}$ & .09 & $.29 * * *$ & & & & & & & \\
\hline 11 Age $(\log )$ & 1.70 & 0.05 & $.19^{*}$ & .01 & .00 & .07 & .07 & -.13 & $-.26 * * *$ & -.11 & $.39 * * *$ & $.62 * * *$ & & & & & & \\
\hline 12 Support/discretion & 3.47 & 0.83 & .13 & .00 & -.11 & $.20^{*}$ & -.04 & -.04 & .03 & .10 & $-.19 *$ & -.15 & $-.16^{*}$ & & & & & \\
\hline 13 Resources & 3.12 & 0.80 & $.23 * *$ & -.04 & .01 & .02 & .01 & -.05 & -.08 & -.14 & .07 & .08 & .16 & $.28 * * *$ & & & & \\
\hline 14 KPI focus & 4.77 & 0.75 & $.21^{* *}$ & -.15 & .04 & -.04 & .12 & -.11 & -.09 & $-.20 *$ & .07 & .16 & .09 & $-.24 * *$ & -.02 & & & \\
\hline 15 Goal ambiguity & 4.91 & 0.79 & $.18^{*}$ & $-.16^{*}$ & $-.21 * *$ & -.06 & .12 & .05 & .14 & -.05 & .05 & -.11 & -.10 & .12 & -.09 & $.29 * * *$ & & \\
\hline 16 Expectations & 4.56 & 0.63 & $.28 * * *$ & .11 & .04 & .00 & -.10 & .00 & .07 & -.02 & .00 & -.02 & .00 & .06 & .04 & .13 & .10 & \\
\hline 17 Localism & 4.72 & 0.71 & $.41 * * *$ & $-.33 * * *$ & $-.17 *$ & .02 & $.17 *$ & -.15 & -.01 & -.12 & $.27 * * *$ & .09 & $.17 *$ & .07 & $.18^{*}$ & $.37 * * *$ & $.28 * * *$ & $.16^{*}$ \\
\hline
\end{tabular}

Note $N=152$

${ }^{\mathrm{a}}$ Coded as dummy variable.

$* p<.05 ; * * p<.01 ; * * * p<.001$ 
Table 2

Results of OLS Analysis with Entrepreneurial Orientation as Dependent Variable

\begin{tabular}{|c|c|c|c|c|}
\hline Variables & Model 1 & Model 2 & Model 3 & Model 4 \\
\hline (Constant) & $3.50 * * *(.65)$ & $.75(1.92)$ & $-.02(1.8)$ & $-2.65(1.82)$ \\
\hline Department size $(\log )$ & $.22(.25)$ & $.16(.24)$ & $.14(.23)$ & $.34(.23)$ \\
\hline Strategy group II $^{\mathrm{a}}$ & $-.17(.20)$ & $-.07(.19)$ & $-.04(.18)$ & $.01(.17)$ \\
\hline Strategy group III $^{\mathrm{a}}$ & $-.03(.17)$ & $-.02(.16)$ & $-.06(.16)$ & $.03(.15)$ \\
\hline Strategy group IV ${ }^{\mathrm{a}}$ & $.35 *(.17)$ & $.34 *(.16)$ & $.34 *(.16)$ & $.41 * *(.15)$ \\
\hline Strategy group $\mathrm{V}^{\mathrm{a}}$ & $-.08(.17)$ & $-.08(.17)$ & $-.06(.16)$ & $.05(.15)$ \\
\hline Employee $^{\mathrm{a}}$ & & $.44(.18)$ & $.49(.17)$ & $.46(.16)$ \\
\hline Civil servant on leave ${ }^{a}$ & & $.11 *(.16)$ & $.13^{* *}(.16)$ & $.22 * *(.15)$ \\
\hline Position/departmental tenure (log) & & $.92 * * *(.25)$ & $.99 * * *(.25)$ & $.84 * * *(.24)$ \\
\hline Organization tenure $(\log )$ & & $-.01(.41)$ & $.08(.39)$ & $.01(.36)$ \\
\hline Age $(\log )$ & & $1.32(1.24)$ & $1.17(1.21)$ & $1.03(1.12)$ \\
\hline Support/discretion & & & $.13 *(.07)$ & $.12(.06)$ \\
\hline Resources & & & $.14 *(.07)$ & $.12 *(.06)$ \\
\hline KPI focus & & & & $.14(.07)$ \\
\hline Goal ambiguity & & & & $.01(.06)$ \\
\hline Expectations & & & & $.22 * *(.07)$ \\
\hline Localism & & & & $.19 *(.08)$ \\
\hline$R^{2}$ & .07 & .20 & .27 & .41 \\
\hline Adjusted $R^{2}$ & .04 & .14 & .20 & .34 \\
\hline$F$ & 2.20 & $3.52 * * *$ & $4.22 * * *$ & $5.77 * * *$ \\
\hline$R^{2}$ change & .07 & .13 & .07 & .14 \\
\hline$F$ change & 2.20 & $4.57^{* * *}$ & $6.37 * *$ & $7.91 * * *$ \\
\hline
\end{tabular}

\section{DISCUSSION}

\section{Benefiting from Different Lenses}

Early in this article, we described how public organizations were affected by the introduction of private sector management principles and that public sector organizations are expected to become more entrepreneurially oriented. A review of literature suggested organizational antecedents established in the private sector could foster public sector EO. Also within the public management discourse, the notion of entrepreneurship has been discussed extensively. The discussion of NPM and PVM in particular raised questions as to whether additional antecedents play key roles in fostering EO in public sector organizations. Adapting private sector antecedents and adding public sector-specific antecedents has proven empirically beneficial. In our sample of 250 managers from 152 departments (agencies) of Germany's FLA, we find not only some support for the importance of established organizational antecedents but also for two antecedents associated with PVM (multitude of expectations and localism). These findings have important implications for both private and public sector scholars.

First of all, we see that no one normative concept (neither NPM nor PVM) can provide sufficient answers. As we are aware that much public management discourse is shaped by doctrine-based assumptions about public sector institutions' mission and performance, we 
believe that our insights into the mechanisms at work can only be advanced by taking multiple rationalities into account.

The results of our first set of hypotheses indicate that a conscious transfer of concepts from the private sector to the public sector is worthwhile and helps further our understanding of the phenomenon under study. With regard to corporate entrepreneurship, our research contributes by validating organizational antecedents in a different context, especially in middle management. There have been explicit calls for the assessment of corporate entrepreneurship outside the private sector (Phan et al. 2009, 204). We provide initial evidence, consistent with private sector research (Hornsby, Kuratko, and Zahra 2002; Hornsby et al. 2009; Kuratko et al. 2005), that management support (H1a), work discretion (H1b), and resource availability (H1d) positively influence department-level EO in the public sector as well. When overlooking other antecedents included in this study, these antecedents have significant positive effects, despite the fact that our data derives from one organization. This underpins Marginson's (2002) observation of the importance of perception, rather than just the manifest structure or organizational design. Nevertheless, the effect of these antecedents is limited and diminishes slightly when considering additional antecedents. However, the results lead us to speculate about sector-independent antecedents. It comes as no surprise that a supportive culture - which offers support in difficult situations instead of blaming — pays off in terms of EO, as does some control over resources and leeway. In other words, our results may foster discussions about general human tendencies with regard to what has been labeled EO in existing organizations. In fact, Bozeman and Kingsley (1998) provide empirical evidence that the organization's sector can hardly explain the variance between organizations' risk cultures. Risk culture was rather accounted for by factors, such as top managers' willingness to trust employees.

The results of our second set of hypotheses weigh against undifferentiated NPM criticism. Scholars and practitioners have claimed that a strong focus on clear, quantifiable goals could negatively affect a public sector organization's performance. Within our context, we find no evidence for such claims with regard to EO. Since the entrepreneurial aspect of the public manager's task is only one aspect of his or her duties besides managing routine work, our data can only be interpreted in this specific realm: KPI focus (H2a) does not have a negative effect on EO; in fact, it has a (nonsignificant) positive effect. This finding is consistent with Marginson $(2002,1026)$, who finds no discouraging effect of KPI use on the development of initiatives and new ideas. Whether or not middle managers (here, department managers) act entrepreneurially is thus neither hindered nor substantially fostered by a strong KPI focus. At least in the FLA, a concern about figures does not impede a sense of EO in middle managers. Given our study design, we cannot exclude a more subtle relationship. For example, the KPI focus for all manager task aspects may indirectly support entrepreneurship since it ensures sufficient performance in the core areas prior to starting new initiatives. In sum, our results can be interpreted as a plea for a differentiated criticism of performance management's NPM-based practices.

The second antecedent tested in this context, goal ambiguity ( $\mathrm{H} 2 \mathrm{~b})$, does not have any effect on EO in our overall sample. One explanation could be that managers react to goal ambiguity in different ways, as anticipated by Ramamurti (1986). Entrepreneurial managers can deal with the associated uncertainty, whereas others might be hindered from taking on a more strategic, that is, entrepreneurial role (Currie and Procter 2005). It should once more be noted that both antecedents were measured within one organization with 
a fairly similar overall structure, thus possibly providing limited variance. Yet, another explanation, underpinned by the observed variance in the constructs (table 1), appears more appropriate: the organizational antecedents have limited explanatory power. This is very much in line with the findings of Meynhardt and Metelmann (2009), who note that the organizational setting is not a primary source of role conflict in the FLA.

The results of our third set of hypotheses support scholars promoting PVM. An active involvement in the immediate local environment seems to foster EO. Multitude of expectations (H3a) has a strong effect on managerial action and fosters EO, as anticipated by Meynhardt and Metelmann (2009). Local community needs and key stakeholders play an important role in defining and achieving public sector entrepreneurial opportunities. This relates to the support we find for $\mathrm{H} 3 \mathrm{~b}$ : EO is positively affected by middle management localism, that is, their willingness and desire to fulfill local community needs. Public middle managers span boundaries between internal and external expectations and thereby contribute to the ever-developing relationship between an organization and its environment. Consequently, critics of public entrepreneurship could question their self-interest and motivation (see Rhodes and Wanna 2007). Further studies might also explore the extent to which the motivation to belong to a certain status group in a certain environment (e.g., social identity and reputation) qualifies as an antecedent of sensitivity to perceive a multitude of expectations, willingness to relate to the local context, and the desire to stay in a role for a longer period of time (position tenure).

The most important determinant of department-level EO in our study is tenure in current position/department. Interpretation of this tenure type appears most fruitful together with multitude of expectations and localism. Such a local involvement should help managers gain access to relevant partners and spot entrepreneurial opportunities. Building networks outside the organization and/or within the department (Floyd and Wooldridge 1999, 133) appears more relevant than within the rest of the organization: organizational tenure does not significantly affect EO. Although the importance of embeddedness and social networks for corporate entrepreneurship (e.g., Floyd and Wooldridge 1999; Simsek, Lubatkin, and Floyd 2003) has been emphasized, there is little empirical research on the interplay between tenure, embeddedness, and EO in the private sector. Together, all three sets of hypotheses help achieve a better understanding of the EO phenomenon. Interestingly, stimuli external to the organization are of special importance.

\section{Toward an Understanding of Social Context}

Compared to the other antecedents, the special importance of factors external to the organization was not obvious beforehand. One can argue that ideas of PVM have helped with reconsidering the role of environmental contingencies for EO. As our study shows, entrepreneurship in the FLA is directed toward PV, but even from a PVM viewpoint, the explanatory power of EO's social context cannot be taken for granted. Therefore, we encourage more research into how drivers external to a public organization complement the internal ones.

In order to solve this puzzle, we take up the abovementioned call by Kelman to better "connect to the broader world of mainstream organization theory" $(2005,967)$. An attractive candidate for introducing such an outside-in perspective to public entrepreneurship is the discourse on institutional entrepreneurship, which looks beyond available resources and efficiency concerns (Bruton, Ahlstrom, and Li 2010). We follow the basic concept of 
DiMaggio, who argues that institutional entrepreneurship is about the creation of "a whole new system of meaning that ties the functioning of disparate sets of institutions together" $(1988,14)$. The term "institution" refers to values, rules, and norms, which create a context of expectations for individual and collective action. Consequently, a public organization's influence on such institutions can be seen as PV creation (or destruction) (Meynhardt 2009). Through its effects, public institutional entrepreneurship may lead to new organizational settings as well as initiatives to develop new services and interaction patterns that are operated by a number of constituencies, rather than solely by the administration. Such a PVM does not imply an expansion of the state but a conscious effort to facilitate and improve the achievement of a legal mandate. In this sense, public entrepreneurship, which is directed at increasing PV, does not face a legitimacy issue per se. However, where political legitimization starts and ends is a matter of degree.

For middle managers in the FLA, public institutional entrepreneurship is about spotting labor market-oriented needs in their district and turning them into institutional opportunities. In this view, engaged public sector managers strive-within a given legal mandate - for new institutional services and add value for the public by realizing them. In respect of middle managers' role in the public sector, we hold that entrepreneurial behavior becomes institutional when it begins to recognize opportunities in the social context.

Empirical evidence now encourages also seeing EO in the public sector from an institutional entrepreneurship viewpoint, which emphasizes context variables, such as culture, regulatory structures, as well as cognitive factors as important determinants of entrepreneurship (Bruton, Ahlstrom, and Li 2010). Research is needed on institutional settings that enable and constrain public entrepreneurship. When does an administration become entrepreneurial? And does this take place to fill structural gaps or is it triggered by external shocks? Research on how the subject position of certain actors comes into play, that is, to what extent institutional entrepreneurs can bridge diverse stakeholders or require a certain legitimacy provided by their social status (Maguire, Hardy, and Lawrence 2004). The enabling role of individuals' social position (Battilana 2006) may therefore be yet another area to deepen our understanding of EO. A third possible research area may be the discursive and political practices developed by entrepreneurs to effectively leverage their agency (Maguire, Hardy, and Lawrence 2004; Reay, Golden-Biddle, and Germann 2006). Along these lines, we can empirically ground the way in which institutional change is promoted at individual actors' micro level by harnessing opportunities in the local environment.

We believe this institutional perspective provides us with a number of interesting research questions. Nonetheless, the linkages between institutional theory and entrepreneurship are complex (Bruton, Ahlstrom, and Li 2010) and "low hanging fruits" should not be expected. Nevertheless, our study might pave the way for providing public management research with new institutional variables. In effect, this more mainstream organizational theory discourse lens may also help dissolve the battlefield of normative arguments associated with NPM and PVM.

\section{Practical Implications}

Our findings might also have important practical implications, especially for top management and HR policies. Most importantly, the data indicate that middle managers should not be forced to rotate positions too frequently. They need time and should be encouraged to 
build local networks that provide them with access to a "multitude of expectations." Developing an understanding of and caring about local circumstances also promotes EO. Another key insight from our study is the importance of fostering active network engagement as a new practice relevant for MCS. As a matter of interest, based on our study, the FLA has introduced managerial performance indicators to integrate localism into the KPI system. Finally, it is crucial for top management to ensure organizational support whenever possible, especially in the form of resources for the implementation of new ideas.

\section{Limitations}

Despite these contributions, this study still has some limitations, which mostly relate to internal and external validity (Bryman 2008, 694; Cook and Campbell 1976, 226). Concerning internal validity, measurements, data, and analytical procedures imply potential limitations. First, the way in which the constructs were measured may be imperfect. Although all measures used multiple items, were inspired by existing research, and were extensively tested, none of the measures could be employed without adjustments. This potentially imperfect operationalization resulted in the exclusion (rewards/recognition) or modification (management support and expectations) of constructs. Furthermore, this study's results may still be affected by common method bias (Podsakoff et al. 2003). However, the consistency in EO ratings from multiple sources indicates limited concern. Yet, all main analyses are based on self-reports and can potentially include biased (e.g., socially expected) answers. To overcome such potential biases, future research might seek to use different measures and to obtain data on dependent and independent variables from different sources.

Second, the nature of data collected limits the type of conclusions and the methods of analysis. The use of cross-sectional data requires caution when drawing causal inferences. The relationships identified in this study may be affected by an exogenous variable not included in this analysis or be prone to reverse causality (Backhaus et al. 2008, 11.1.2.1). Although the hypotheses are based on theoretical considerations, mechanisms other than the assumed ones could underlie the identified relationships. Data reflecting developments over time could help overcome such uncertainty. In addition, a larger sample size would allow for the application of a wider range of analytical tools, such as weighted least squares estimation in the CFA.

Third, this study did not analyze the effects of mediation, moderation, or interaction among many of the constructs (Lumpkin and Dess 1996, 156; Venkatraman 1989). One important avenue of research is therefore to better understand the interplay between the constructs identified as most relevant in this research: position/department tenure, localism, multitude of expectations, and EO.

When evaluating this study's external validity, it seems helpful to distinguish between the generalizability of its results to FLA middle management and outside the organization. We have addressed results generalizability to the FLA in the section on external validity and have identified reasons for limited concern in this regard. However, although our findings are at least partly in line with prior research, and culture has had a limited influence in the study of EO (Rauch et al. 2009, 779), further studies are needed to assess the findings' generalizability to other organizations and cultural settings. Such studies could address similar contexts, where our results may be most relevant, such as in other labor market-related public organizations or other public organizations operating in a Rechtsstaat culture (Pollitt 
and Bouckaert 2004, 52-3). Furthermore, studies in more dissimilar settings would strengthen this study's arguments.

Despite all methodological challenges facing this study's generalizability, we hold that, with its specific conditions, the FLA can be regarded as an exemplary public entrepreneurship case, with the contribution lying in the generalization of theory and not necessarily of other cases (Yin 1984, 39).

\section{CONCLUSION}

In conclusion, this study provides initial insights into what determines department-level EO in public sector organizations. Although further work is required to strengthen the findings, they confirm established private sector corporate entrepreneurship research on organizational antecedents and support PVM ideas. At the same time, the findings contradict NPM critics who assert negative effects of KPI focus and goal ambiguity on middle management entrepreneurial behavior. Our results at least differentiate and qualify this general assertion. As we integrated hypotheses based on ideas from the private sector, the NPM movement, and the emerging PVM perspective, we distilled antecedents that are at the heart of public sector entrepreneurship and are in part similar to the private sector and in part unique to the public sector. To consider "what is" rather than "what should be" may help us develop an appreciative and evidence-based notion of the nature of entrepreneurship in public administration. Given the tremendous challenges faced by the public sector, it is much needed.

\section{APPENDICES}

\section{Table A1}

Scale Items

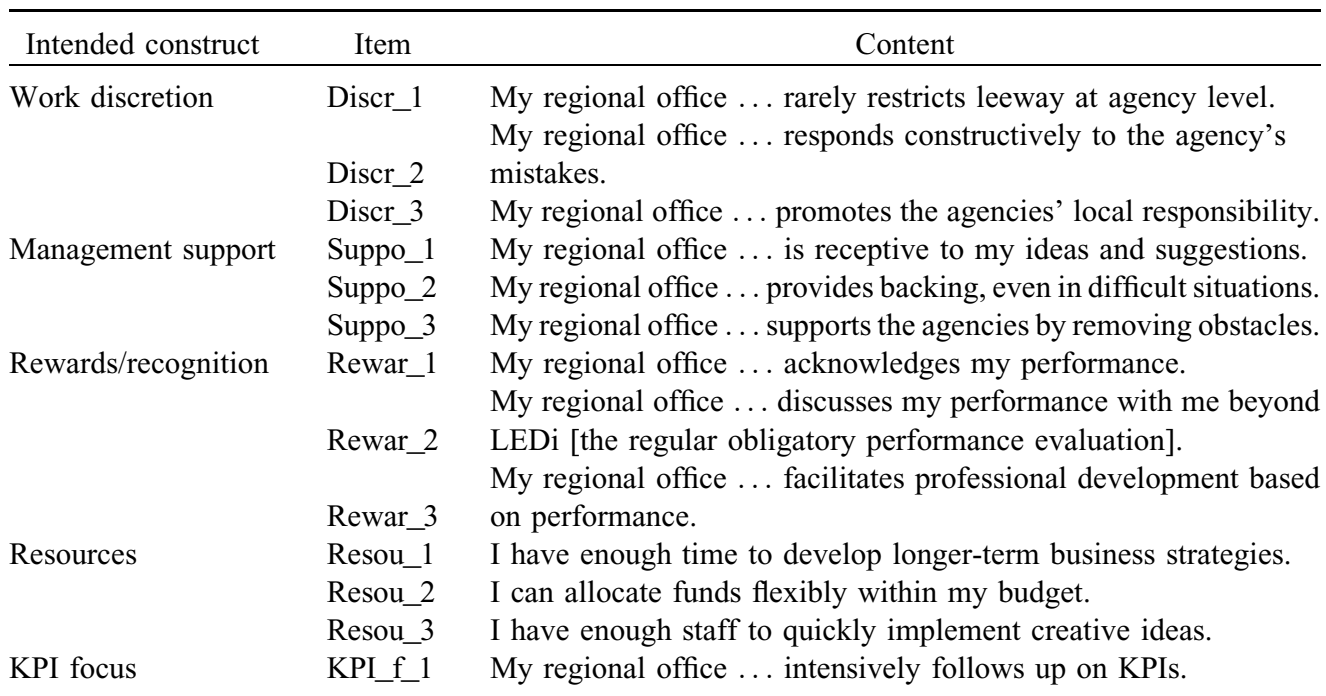


Goal ambiguity

Expectations

Localism

EO dimensions Innovativeness

Proactiveness

Risk taking
KPI_f_2

KPI_f_3 My regional office ... manages mainly by means of KPIs.

KPI_f_4 My regional office ... places heavy emphasis on KPIs.

My regional office ... only places emphasis on activities directly KPI_f_5 affecting KPIs.

The prescribed/agreed business objectives ... are extremely

Goals_1 numerous.

The prescribed/agreed business objectives ... are contradictory in

Goals_2 some aspects.

Goals_3 complex overall.

Local actors in the labor market (employers' associations, unions, politics, etc.). In my district, . . the local actors' expectations of the Expec_1 agency are very diverse.

In my district, ... the local actors' expectations on the agency are

Expec_2 high.

In my district, ... the expectations of several local actors are

Expec_3 contradictory in some aspects.

In my district, ... local actors influence many decisions at the

Expec_4 agency level.

In my district, ... I frequently receive proposals from the local

Expec_5 environment.

The management committee frequently expresses specific

Expec_6 expectations.

Local_1 Personally, I really feel at home in my district.

How many organizations operating in your district do you work for

Local_2 voluntarily?

In fulfilling my task, it is personally especially important to me ...

Local_3 to satisfy local needs in the district.

In fulfilling my task, it is personally especially important to me ...

Local_4 to act as a competent partner in the network of local actors.

My agency in its entirety...

Innov_1 is open to innovations.

Innov_2 is creative.

Innov_3 is innovative.

Innov_4 often implements new approaches to meet its responsibilities.

Proac_1 rarely behaves hesitantly. (Reverse)

Proac_2 responds to [labor/training] market changes as they occur.

Proac_3 responds mostly actively to [labor/training] market changes.

Proac_4 often approaches external groups to initiate projects.

Risk_1 also implements promising but risky projects.

also implements projects with no direct effect on the target

Risk_2 system's KPIs.

Risk_3 often gets involved, even if the outcome is initially uncertain.

Risk_4 often enters ventures to promote particularly promising projects.

Risk_5 is especially careful in its course of action. (Reverse) 
Table A2

Results of Exploratory Factor Analysis

\begin{tabular}{|c|c|c|c|c|c|c|c|c|c|c|}
\hline Intended construct & Item & 1 & 2 & 3 & 4 & 5 & 6 & 7 & 8 & 9 \\
\hline Work discretion & Discr_1 & .68 & & & & & & & & \\
\hline Work discretion & Discr_2 & .73 & & & & & & & & \\
\hline Work discretion & Discr_3 & .81 & & & & & & & & \\
\hline Management support & Suppo_1 & .73 & & & & & & & & \\
\hline Management support & Suppo_2 & .79 & & & & & & & & \\
\hline Management support & Suppo_3 & .73 & & & & & & & & .30 \\
\hline Rewards/Recognition & Rewar_1 & .46 & .79 & & & & & & & \\
\hline Rewards/Recognition & Rewar_2 & .43 & .58 & & & & & & & \\
\hline Rewards/Recognition & Rewar_3 & .52 & .63 & & & & & & & \\
\hline Resources & Resou_1 & & & .55 & & & & & & \\
\hline Resources & Resou_2 & & & .55 & & & & & & \\
\hline Resources & Resou_3 & & & .82 & & & & & & \\
\hline KPI focus & KPI_f_1 & & & & .72 & & & & & \\
\hline KPI focus & KPI_f_2 & & & & .82 & & & & & \\
\hline KPI focus & KPI_f_3 & & & & .83 & & & & & \\
\hline KPI focus & KPI_f_4 & & & & .85 & & & & & \\
\hline KPI focus & KPI_f_5 & -.34 & & & .63 & & & & & \\
\hline Goal ambiguity & Goals_1 & & & & & .81 & & & & \\
\hline Goal ambiguity & Goals_2 & & & & & .46 & & & & \\
\hline Goal ambiguity & Goals_3 & & & & & .61 & & & & \\
\hline Expectations & Expec_1 & & & & & & .83 & & & \\
\hline Expectations & Expec_2 & & & & & & .61 & & & .35 \\
\hline Expectations & Expec_3 & & & & & & .39 & & & \\
\hline Expectations & Expec_4 & & & & & & & .69 & & \\
\hline Expectations & Expec_5 & & & & & & & .55 & & \\
\hline Expectations & Expec_6 & & & & & & & .36 & & .59 \\
\hline Localism & Local_1 & & & & & & & & .58 & \\
\hline Localism & Local_2 & & & & & & & & .42 & \\
\hline Localism & Local_3 & & & & & & & & .46 & \\
\hline Localism & Local_4 & & & & .34 & & & & .44 & \\
\hline
\end{tabular}

Table A3

Fit Indices Confirmatory Factor Analysis

\begin{tabular}{lrrrcrrr}
\hline \multicolumn{1}{c}{ Measurement model } & \multicolumn{1}{c}{$\chi^{2}$} & \multicolumn{1}{c}{ df } & $\chi^{2} / \mathrm{df}$ & RMSEA & SRMR & CFI & TLI \\
\hline Independent variables: Initial & 637 & 377 & 1.69 & .07 & .07 & .87 & .85 \\
Independent variables: Trimmed & 180 & 137 & 1.31 & .05 & .06 & .95 & .94 \\
Dependent variables: Initial & 117 & 62 & 1.89 & .08 & .06 & .95 & .93 \\
Dependent variables: Trimmed & 38 & 24 & 1.58 & .06 & .04 & .98 & .97 \\
Complete measurement model & 406 & 314 & 1.29 & .04 & .06 & .95 & .94 \\
\hline Note. Analysis conducted in analysis of moment structures using maximum likelihood estimation. $N=152$. \\
\hline
\end{tabular}


Figure A1

Specification CFA

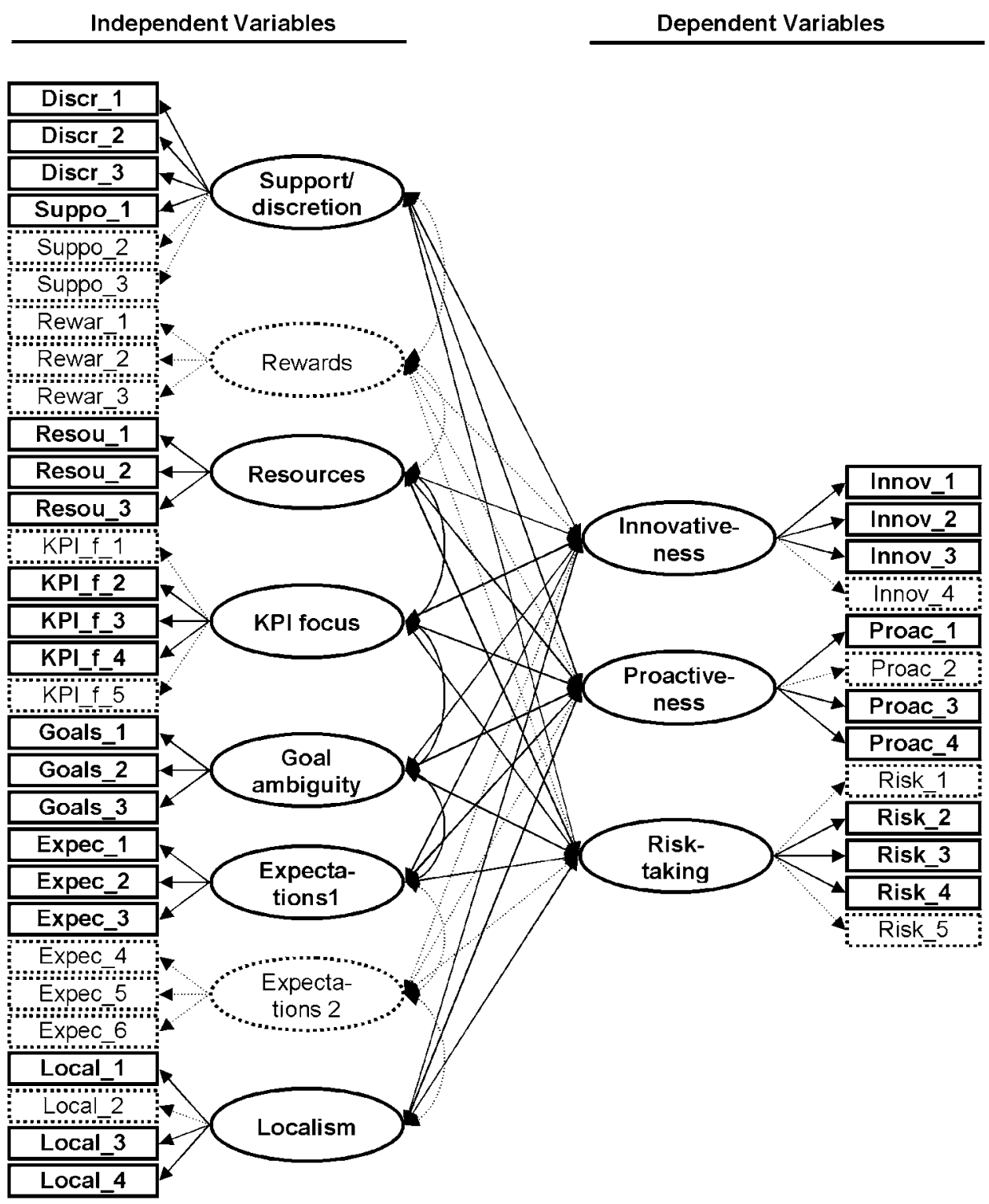

Note. Dotted items and constructs not included in regression analysis. Not displaying error terms and not displaying all covariances between constructs.

\section{REFERENCES}

Antoncic, Bostian. 2007. Intrapreneurship: A comparative structural equation modeling study. Industrial Management \& Data Systems 107:309-25.

Antoncic, Bostian, and Robert D. Hisrich. 2001. Intrapreneurship: Construct refinement and cross-cultural validation. Journal of Business Venturing 16:495-527. 
Armstrong, Scott J., and Terry S. Overton. 1977. Estimating nonresponse bias in mail surveys. Journal of Marketing Research 14:396-402.

Backhaus, Klaus, Bernd Erichson, Wulff Plinke, and Rolf Weiber. 2008. Multivariate Analysemethoden: Eine anwendungsorientierte Einführung. 12 vollst. überarb. Aufl. Springer-Lehrbuch. Berlin, Germany: Springer.

Bagozzi, Richard P., and Youjae Yi. 1988. On the evaluation of structural equation models. Journal of the Academy of Marketing Science 16:74-94.

Balogun, Julia. 2003. From blaming the middle to harnessing its potential. Creating change intermediaries. British Journal of Management 14:69-83.

Barringer, Bruce R., and Allen C. Bluedorn. 1999. The relationship between corporate entrepreneurship and strategic management. Strategic Management Journal 20:421-44.

Battilana, Julie. 2006. Agency and institutions: The enabling role of individuals' social position. Organization 13:653-76.

Bellone, Carl J., and Georg Frederik Goerl. 1992. Reconciling public entrepreneurship and democracy. Public Administration Review 52:130-4.

Bennington, John, Marc H. Moore (eds.). 2011. Public value. Theory and practice. New York, NY: Palgrave Macmillan.

Bernier, Luc, and Taïbe Hafsi. 2007. The changing nature of public entrepreneurship. Public Administration Review 67:488-503.

Bevan, Gwyn, and Christopher Hood. 2006. What's measured is what matters: Targets and gaming in the English public health care system. Public Administration 84:517-38.

Bliese, Paul D. 2000. Within-group agreement, non-independence, and reliability: Implications for data aggregation and analysis. In Multilevel theory, research, and methods in organizations: Foundations, extensions, and new directions, ed. Katherine J. Klein and Steve W. J. Kozlowski, 349-81. San Francisco, CA: Jossey-Bass.

Borins, Sandford. 2000. Loose cannons and rule breakers, or enterprising leaders? Some evidence about innovative public managers. Public Administration Review 60:498-507.

Bozeman, Barry, and Gordon Kingsley. 1998. Risk culture in public and private organizations. Public Administration Review 58:109-18.

Bracht, Glenn H., and Gene V. Glass. 1968. The external validity of experiments. American Educational Research Journal 5:437-74.

Bruton, Garry D., David Ahlstrom, and Han-Lin Li. 2010. Institutional theory and entrepreneurship: Where are we now and where do we need to move in the future? Entrepreneurship: Theory \& Practice 34:421-40.

Bryman, Alan. 2008. Social research methods, 3rd ed. Oxford, NY: Oxford Univ. Press.

Bundesagentur für Arbeit. 2011. Projekt "Meer Arbeit": Willkommen zur Kreuzfahrt-Jobbörse. Nürnberg: Bundesagentur für Arbeit. http://www.arbeitsagentur.de/nn_386092/Navigation/ Dienststellen/RD-SAT/Suhl/Agentur/Ueber-Uns/Projekt-Meer-Arbeit/Projekt-Meer-Arbeit-Nav.html (accessed March 31, 2011).

Burgelman, Robert A. 1983a. A process model of internal corporate venturing in the diversified major firm. Administrative Science Quarterly 28:223-44.

. 1983b. Corporate entrepreneurship and strategic management: Insights from a process study. Management Science 29:1349-64.

. 1985. Public entrepreneurship: Toward a theory of bureaucratic political power. Administrative Science Quarterly 30:594-6.

Christiensen, Tom, Per Lægreid, Paul G. Roness, and Kjell Arne Røvik. 2007. Organization theory and the public sector: Instrument, culture and myth. Abingdon, UK: Routledge.

Churchill, Gilbert A., Jr. 1979. A paradigm for developing better measures of marketing constructs. Journal of Marketing Research 16:64-73.

de Clercq, Dirk, Dimo Dimov, and Narongsak Thongpapanl. 2010. The moderating impact of internal social exchange processes on the entrepreneurial orientation-performance relationship. Journal of Business Venturing 25:87-103. 
Cohen, Jacob. 1988. Statistical power analysis for the behavioral sciences. 2nd ed. Hillsdale, NJ: Lawrence Erlbaum Associates.

Coleman, James S. 1988. Social capital in the creation of human capital. The American Journal of Sociology 94:S95-S120.

Cook, Thomas D., and Donald T. Campbell. 1976. The design and conduct of quasi-experiments and true experiments in field settings. In Handbook of industrial and organizational psychology, ed. Marvin D. Dunnette, 223-326. Chicago, IL: Rand McNally College.

Covin, Jeffrey G., and Dennis P. Slevin. 1989. Strategic management of small firms in hostile and benign environments. Strategic Management Journal 10:75-87.

—. 1991. A conceptual model of entrepreneurship as firm behavior. Entrepreneurship Theory and Practice 16:7-25.

Currie, Graeme, Mike Humphreys, Deniz Ucbasaran, and Steve McManus. 2008. Entrepreneurial leadership in the English public sector: Paradox or possibility? Public Administration 86:987-1008.

Currie, Graeme, and Stephen J. Procter. 2005. The antecedents of middle managers' strategic contribution: The case of a professional bureaucracy. Journal of Management Studies 42:1325-56.

Cyert, Richard M., and James G. March. 1992. A behavioral theory of the firm. 2nd ed. Malden, MA: Wiley-Blackwell.

Dauth, Wolfgang, Franziska Hirschenauer, and Felix Rüb. 2008. Neue Typisierung regionaler Arbeitsmärkte: Damit Äpfel nicht mit Birnen verglichen werden ... . IAB-Kurzbericht 15. Nürnberg, Germany: Institut für Arbeitsmarkt- und Berufsforschung. http://doku.iab.de/kurzber/2008/ kb1508.pdf (accessed February 11, 2010).

deLeon, Linda, and Robert B. Denhardt. 2000. The political theory of reinvention. Public Administration Review 60:89-97.

DiMaggio, Paul. 1988. Interest and agency in institutional theory. In Institutional patterns and organizations, ed. L. Zucker, 3-22. Cambridge, MA: Ballinger.

Drucker, Peter F. 1993. The practice of management. Reed international books. Oxford, UK: ButterworthHeinemann.

Du Gay, Paul. 2000. In praise of bureaucracy: Weber, organization, ethics. London: Sage.

Floyd, Steven W., and Peter J. Lane. 2000. Strategizing throughout the organization: Managing role conflict in strategic renewal. Academy of Management Review 25:154-77.

Floyd, Steven W., and Bill Wooldridge. 1997. Middle management's strategic influence and organizational performance. Journal of Management Studies 34:465-85.

- 1999. Knowledge creation and social networks in corporate entrepreneurship: The renewal of organizational capability. Entrepreneurship Theory and Practice 23:123-43.

Fornell, Claes, and David F. Larcker. 1981. Evaluating structural equation models with unobservable variables and measurement error. Journal of Marketing Research 18:39-50.

Guth, William D., and Ari Ginsberg. 1990. Guest editor's introduction: Corporate entrepreneurship. Strategic Management Journal 11:5-15.

Guth, William D., and Ian C. MacMillan. 1986. Strategy implementation versus middle manager selfinterest. Strategic Management Journal 7:313-27.

Hair, Joseph F., Bill Black, Barry Babin, and Rolph E. Anderson. 2010. Multivariate data analysis: A global perspective. 7th ed. Upper Saddle River, NJ: Pearson.

Hinkin, Timothy R. 1995. A review of scale development practices in the study of organizations. Journal of Management 21:967-88.

Hisrich, Robert D., and Michael P. Peters. 1986. Establishing a new business venture unit within a firm. Journal of Business Venturing 1:307-22.

Hood, Christopher. 1991. A public management for all seasons? Public Administration 69:3-19.

Hornsby, Jeffrey S., Donald F. Kuratko, and Ray V. Montagno. 1999. Perception of internal factors for corporate entrepreneurship: A comparison of canadian and US managers. Entrepreneurship Theory and Practice 24:9-24.

Hornsby, Jeffrey S., Donald F. Kuratko, Dean A. Shepherd, and Jennifer P. Bott. 2009. Managers' corporate entrepreneurial actions: Examining perception and position. Journal of Business Venturing 24:236-47. 
Hornsby, Jeffrey S., Donald F. Kuratko, and Shaker A. Zahra. 2002. Middle managers' perception of the internal environment for corporate entrepreneurship: Assessing a measurement scale. Journal of Business Venturing 17:253-73.

Hornsby, Jeffrey S., Douglas W. Naffziger, Donald F. Kuratko, and Ray V. Montagno. 1993. An interactive model of the corporate entrepreneurship process. Entrepreneurship Theory and Practice 17:29-37.

James, Lawrence R. 1982. Aggregation bias in estimates of perceptual agreement. Journal of Applied Psychology 67:219-29.

Kanter, Rosabeth Moss. 1985. Supporting innovation and venture development in established companies. Journal of Business Venturing 1:47-61.

- 1989. When giants learn to dance. New York, NY: Simon and Schuster.

Kanuk, Leslie, and Conrad Berenson. 1975. Mail surveys and response rates: A literature review. Journal of Marketing Research 12:440-53.

Kearney, Claudine, Robert D. Hisrich, and Frank Roche. 2008. A conceptual model of public sector corporate entrepreneurship. The International Entrepreneurship and Management Journal 4:295-313.

Kelly, Gavin, Geoff Mulgan, and Stephen Muers. 2002. Creating public value: An analytical framework for public service reform. London: UK Government. http://www.cabinetoffice.gov.uk/media/ cabinetoffice/strategy/assets/public_value2.pdf (accessed November 29, 2008).

Kelman, Steve. 2005. Public management needs help!. Academy of Management Journal 48:967-9.

Kim, Younhee. 2007. A multidimensional model of public entrepreneurship. PhD diss., Rutgers The State University of New Jersey.

Kuratko, Donald F., R. Duane Ireland, Jeffrey G. Covin, and Jeffrey S. Hornsby. 2005. A model of middlelevel managers' entrepreneurial behavior. Entrepreneurship Theory and Practice 29:699-716.

Lewis, Eugene. 1980. Public entrepreneurship: Toward a theory of bureaucratic political power. The organizational lives of Hyman Rickover, J. Edgar Hoover, and Robert Moses. Bloomington, IN: Indiana Univ. Press.

Lumpkin, G. T., and Gregory G. Dess. 1996. Clarifying the entrepreneurial orientation construct and linking it to performance. Academy of Management Review 21:135-72.

Maguire, Steve, Cynthia Hardy, and Thomas B. Lawrence. 2004. Institutional entrepreneurship in emerging fields: HIV/AIDS treatment advocacy in Canada. Academy of Management Journal 47:657-79.

Mack, W. R., Deanna Green, and Arnold Vedlitz. 2008. Innovation and implementation in the public sector: An examination of public entrepreneurship. Review of Policy Research 25:233-52.

Marginson, David E. W. 2002. Management control systems and their effects on strategy formation at middle-management levels: Evidence from a U.K. organisation. Strategic Management Journal 23:1019-31.

Markowski, Stefan, and Peter Hall. 2007. Public sector entrepreneurialism and the production of defense. Public Finance \& Management 7:260-94.

Meynhardt, Timo. 2008. Public value —oder: Was heißt Wertschöpfung zum Gemeinwohl? der moderne staat 2:457-68.

- 2009. Public value inside: What is public value creation? International Journal of Public Administration 32:192-219.

Meynhardt, Timo, and Steffen Bartholomes. 2011. (De)Composing public value: In search of basic dimensions and common ground, International Public Management Journal 14:284-308.

Meynhardt, Timo, and Jörg Metelmann. 2009. Pushing the envelope: Creating public value in the labor market: An empirical study on the role of middle managers. International Journal of Public Administration 32:274-312.

Miller, Danny. 1983. The correlates of entrepreneurship in three types of firms. Management Science 29:770-91.

Mintrom, Michael. 2000. Policy entrepreneurs and school choice. American governance and public policy series. Washington, DC: Georgetown Univ. Press. 
Moon, Myung Jae. 1999. The pursuit of managerial entrepreneurship: Does organization matter? Public Administration Review 59:31-43.

Moore, Mark Harrison. 1995. Creating public value: Strategic management in government. Cambridge, MA: Harvard Univ. Press.

Morris, Michael H., J. Allen, M. Schindehutte, and R. Avila. 2006. Balanced management control systems as a mechanism for achieving corporate entrepreneurship. Journal of Managerial Issues 18:468-93.

Morris, Michael H., and Foard F. Jones. 1993. Human resource management practices and corporate entrepreneurship: An empirical assessment from the USA. International Journal of Human Resource Management 4:873-96.

. 1999. Entrepreneurship in established organizations: The case of the public sector. Entrepreneurship Theory and Practice 24:71-91.

O'Flynn, Janine. 2007. From new public management to public value: Paradigmatic change and managerial implications. Australian Journal of Public Administration 66:353-66.

Osborne, David, and T. Gaebler. 1992. Reinventing government: How the entrepreneurial spirit is transforming the public sector. New York, NY: Plume.

Pandey, Sanjay K., and James L. Garnett. 2006. Exploring public sector communication performance: Testing a model and drawing implications. Public Administration Review 66:37-51.

Pearce, John A., Tracy Robertson Kramer, and D. Keith Robbins. 1997. Effects of managers' entrepreneurial behavior on subordinates. Journal of Business Venturing 12:147-60.

Pettigrew, Andrew M., Ewan Ferlie, and Lorna McKee. 1992. Shaping strategic change: Making change in large organizations. The case of the National Health Service. London: Sage.

Phan, Philip H., Mike Wright, Deniz Ucbasaran, and Wee-Liang Tan. 2009. Corporate entrepreneurship: Current research and future directions. Journal of Business Venturing 24:197-205.

Podsakoff, Philip M., Scott B. MacKenzie, Jeong-Yeon Lee, and Nathan P. Podsakoff. 2003. Common method biases in behavioral research: A critical review of the literature and recommended remedies. Journal of Applied Psychology 88:879-903.

Podsakoff, Philip M., and Dennis W. Organ. 1986. Self-reports in organizational research: Problems and prospects. Journal of Management 12:531-44.

Pollitt, Christopher, and Geert Bouckaert. 2004. Public management reform: A comparative analysis, 2nd ed. Oxford: Oxford Univ. Press.

Rainey, Hal G. 1983. Public agencies and private firms: Incentive structures, goals, and individual roles. Administration \& Society 15:207-42.

. 2009. Understanding and managing public organizations, 4th ed. San Francisco, CA: JosseyBass.

Ramamurti, Ravi. 1986. Public entrepreneurs: Who they are and how they operate. California Management Review 28:142-58.

Rauch, Andreas, Johan Wiklund, G. T. Lumpkin, and Michael Frese. 2009. Entrepreneurial orientation and business performance: An assessment of past research and suggestions for the future. Entrepreneurship Theory and Practice 33:761-87.

Reay, Trish, Karen Golden-Biddle, and Kathy Germann. 2006. Legitimizing a new role: Small wins and microprocesses of change. Academy of Management Journal 49:977-98.

Rhodes, Rod A. W., and John Wanna. 2007. The limits to public value, or rescuing responsible government from the platonic guardians. Australian Journal of Public Administration 66:406-21.

Rizzo, John R., Robert J. House, and Sidney I. Lirtzman. 1970. Role conflict and ambiguity in complex organizations. Administrative Science Quarterly 15:150-63.

Roberts, Nancy Charlotte., and Paula J. King. 1991. Policy entrepreneurs: Their activity structure and function in the policy process. Journal of Public Administration Research and Theory 1:147-75.

Roof, W. Clark. 1972. The local-cosmopolitan orientation and traditional religious commitment. Sociological Analysis 33:1-15.

Rubin, Donald B. 1976. Inference and missing data. Biometrika 63:581-92.

Sathe, Vijay. 1988. From surface to deep corporate entrepreneurship. Human Resource Management 27:389-411. 
1989. Fostering entrepreneurship in the large, diversified firm. Organizational Dynamics 18:20-32.

Schedler, Kuno, and Isabella Proeller. 2006. New Public Management. 3. vollst. überarb. Aufl. UTB für Wissenschaft. Uni-Taschenbücher 2132, Kleine Reihe. Bern: Haupt.

Schneider, Mark, Paul Eric Teske, and Michael Mintrom. 1995. Public entrepreneurs: Agents for change in American government. Princeton, NJ: Princeton Univ. Press.

Sharma, Pramodita, and James J. Chrisman. 1999. Toward a reconciliation of the definitional issues in the field of corporate entrepreneurship. Entrepreneurship Theory and Practice 23:11-27.

Simsek, Zeki, Michael H. Lubatkin, and Steven W. Floyd. 2003. Inter-firm networks and entrepreneurial behavior: A structural embeddedness perspective: Entrepreneurship: Past accomplishments and future challenges. Journal of Management 29:427-42.

Simsek, Zeki, and John F. Veiga. 2000. The electronic survey technique: An integration and assessment. Organizational Research Methods 3:93-115.

Smith, Peter. 1995. On the unintended consequences of publishing performance data in the public sector. International Journal of Public Administration 18:277-310.

Spiegel Online. 2010. Von der Leyen stellt "Bürgerarbeit" vor. Spiegel Online. http://www.spiegel.de/ politik/deutschland/0,1518,705679,00.html (accessed March 31, 2011).

Steiner, Christine, Friedrich Hauss, Sabine Böttcher, and Burkart Lutz. 2008. Evaluation des Projektes Bürgerarbeit im 1. Flächenversuch Stadt Bad Schmiedeberg. Endbericht. Halle: Institut für Arbeitsmarkt- und Berufsforschung. http://www.arbeits agentur.de/Dienststellen/RD-SAT/RDSAT/A04-Vermittlung/Allgemein/pdf/Endbericht-Buergerarbeit-pdf.pdf (accessed March 31, 2011).

Stoker, Gerry. 2006. Public value management: a new narrative for networked governance? The American Review of Public Administration 36:41-57.

Sykes, Hollister B. 1986. The anatomy of a corporate venturing program: Factors influencing success. Journal of Business Venturing 1:275-93.

Terry, Larry D. 1998. Administrative leadership, neo-managerialism, and the public management movement. Public Administration Review 58:194-200.

Teske, Paul Eric, and Mark Schneider. 1994. The bureaucratic enterpreneur: The case of city managers. Public Administrative Review 54:331-40.

Tietz, Janko. 2008. Mehr Jobs dank Meer. Der Spiegel. http://www.spiegel.de/spiegel/print/d56898828.html (accessed March 31, 2011).

Venkatraman, N. 1989. The concept of fit in strategy research: Toward verbal and statistical correspondence. Academy of Management Journal 14:423-44.

Waldo, Dwight. 1948/2007. The administrative state: A study of the political theory of American public administration. New Brunswick, NJ: Transaction Publishers.

Wood, Christopher C., Daniel T. Holt, Timothy S. Reed, and Bryan J. Hudgens. 2008. Perceptions of corporate entrepreneurship in Air Force organizations: Antecedents and outcomes. Journal of Small Business \& Entrepreneurship 21:117-31.

Wooldridge, Bill, Torsten Schmid, and Steven W. Floyd. 2008. A middle management perspective on strategy process: Current contributions, synthesis and future research. Journal of Management 34:1190-221.

Yin, Robert K. 1984. Case study research: Design and methods. Beverly Hills, CA: Sage.

Zahra, Shaker A. 1991. Predictors and financial outcomes of corporate entrepreneurship: An exploratory study. Journal of Business Venturing 6:259-85.

Zahra, Shaker A., Daniel F. Jennings, and Donald F. Kuratko. 1999. The antecedents and consequences of firm-level entrepreneurship: The state of the field. Entrepreneurship Theory and Practice 24:45-65.

Zerbinati, Stefania, and Vangelis Souitaris. 2005. Entrepreneurship in the public sector: A framework of analysis in European local governments. Entrepreneurship \& Regional Development 17:43-64. 